\title{
Single nucleotide polymorphism markers with applications in aquaculture and assessment of its impact on natural populations
}

\author{
Roman Wenne* \\ Institute of Oceanology, Polish Academy of Sciences, Powstańców Warszawy 55, 81-712 Sopot, Poland
}

Received 16 March 2017 / Accepted 4 November 2017

Handling Editor: Costas Tsigenopoulos

\begin{abstract}
An increase in aquatic animal production can be achieved by extending aquaculture areas geographically, utilizing new species for culture, and using new technologies. Among new technologies useful for the increase of aquaculture production is the application of genetics and genomics. New molecular tools that benefit aquaculture have been developed. There has been a large number of experimental and review papers published concerning molecular markers and the range of their applications, including aquaculture and food product analyses. Analysis of single nucleotide polymorphisms (SNPs) has emerged as genotyping technology with wide and significant applications in aquaculture. SNPs can be used for construction of genetic linkage maps, finding quantitative trait loci (QTL) for useful traits like growth, body weight, grilsing, thermal and low oxygen tolerance, resistance to stress and diseases, mapping sex determination loci and identification of progeny in selection and chromosome manipulation experiments, assessment of genomic selectionand marker assisted selection in aquaculture. Genome-wide association studies (GWAS) facilitate the finding associations between SNPs and a trait in related or unrelated specimens. However, many traits are complex and can be controlled by number of QTL. Genotyping by genome reduction complexity sequencing emerged as an efficient and applicable technology in genomic selection. Identification of genes, sequences and nucleotides (substitutions) directly influencing phenotypic variations opens the possibility of marker-assisted selection for desirable characters in culture. SNP and QTL associations can be enhanced using genome editing technology. Examples of successful applications of SNPs in aquaculture of fish, crustacean and mollusk species, representing most geographic areas, and ecological risks assessment are reviewed.
\end{abstract}

Keywords: Aquaculture and mariculture / identification of escapees / SNP / QTL / resistance to pathogens / genomic selection / gene editing

\section{Introduction}

Exploitation of living marine and freshwater resources is an important source of food for human population worldwide. Global aquatic production has been increasing substantially for over 60 years and reached 167.2 million tonnes in 2014, of which $55.86 \%$ was capture fisheries production (FAO, 2016). However, aquaculture has hugely increased over the last 25 years and shows a higher potential for future development in comparison with capture fisheries. Further increases in production will be achieved by extending aquaculture areas geographically (finding new areas suitable for aquaculture industry), employing new species for culture, and using new technologies. A technology developed in recent years and useful for increasing aquaculture

*Corresponding author: rwenne@iopan.gda.pl production and improving the protection of biodiversity is the application of genomics (McAndrew and Napier, 2010; Abdelrahman et al., 2017; Macqueen et al., 2017). New Generation Sequencing (NGS) has enabled the assembly of genomes of an increasing a number of species, and the characterization of number of genes in some cultured species has been followed by the characterization of their gene pools. This has, in turn, lead to functional studies of genes relevant to the goals of aquaculture. Genotyping by sequencing (GBS) techniques have laid the foundation for advances in aquaculture genetics and breeding (Robledo et al., 2017). Genome complexity reduction has facilitated the discovery of a large number of molecular markers, especially single nucleotide polymorphism (SNP). A range of techniques have been used for SNP discovery. The smaller scale methods include SSCP and heteroduplex analyses, random shotgun, direct polymerase chain reaction (PCR) product sequencing and expressed 
sequence tags (ESTs) (Liu and Cordes, 2004). Large scale SNP discovery enabled with high throughput sequencing platforms NGS and whole genome sequencing in fish has been reviewed more recently (Abdelrahman et al., 2017; Kumar and Kocour, 2017). SNP have been used for the identification of brood stocks, traits and strains in aquaculture. SNP can be applied to finding candidate genes of traits and quantitative trait loci (QTL) useful in aquaculture (Oyarzún etal., 2013; Yáñez et al., 2015).QTL are genomic regions associated with phenotypic variation for a specific trait, which can be significant for aquaculture, such as growth, skin pigmentation, body shape, color of meat, age of maturity (grilsing), thermal tolerance, lipid metabolism and resistance to stress and diseases.

Selective breeding of farmed animals for economically important quantitative traits has high potential for increasing aquaculture production. In classic selection schemes best linear unbiased prediction (BLUP) is applied to assess the selection candidates based on the phenotypes of relatives without the use of genetic markers (Boichard et al., 2016). In order to reinforce phenotypic based selection QTL markers were developed with the intended applications in marker assisted selection (MAS). The identified QTL for economically useful traits in aquaculture have been summarized recently (Abdelrahman et al., 2017). Linkage analysis to detect QTL includes family and progeny data (Rabier et al., 2016). Segregation of QTL has been studied within family. MAS can be successful if significant variance explained by a QTL (association) is not overestimated and linkage disequilibrium between marker and QTL persists throughout the population. Alternatively, large number of markers covering whole genome can be used for estimation of breeding value (Meuwissen et al., 2001). Genotyping with high density markers can shorten generation phase. Genome-wide association studies (GWAS) seek to find associations between SNPs and traits in unrelated specimens. However, many traits are complex and can be controlled by number of QTL. Genomic selection (GS) involves prediction of breeding values of selection candidates using high density markers irrespective of significance in their association studies. GS relies on the assumption that some QTL are in strong linkage disequilibrium with molecular markers (SNPs). Finding functional implications of particular SNP will enable genetic engineering by the incorporation of single nucleotides or short sequences (Dunham et al., 2014). Such alterations can make alleles in aquaculture more alike to the alleles of specimens with desirable characteristics: resistance to infections, growth or meat condition. Comprehensive use of biotechnology in aquaculture is outlined in the paper (FAO, 2017).

\section{Comparison of wild and hatchery stocks: effects of escapees}

One of the ecological risks of aquaculture is the deliberate or unintentional release of farmed fish to the natural environment. Hatchery reared fish are products of strong selection for traits of interest within a species. When released, they can hybridize with naturally born individuals and compromise the genetic integrity and fitness of natural populations. Population genomic analyses of early-phase Atlantic salmon (Salmo salar) revealed only a slight loss of genetic diversity in domesticated strains (Makinen et al., 2015). Genetic differences between farmed and wild Atlantic salmon in Norway were studied using a 7K SNP-chip (Karlsson et al., 2011). A diagnostic panel of only 60 SNPs out of 7000 SNPs was constructed and successfully identified farmed escapees. The genetic impact of gene flow caused by the straying of hatchery released fish on wild populations of Atlantic salmon in the Gulf of Finland, Baltic Sea, over 16 years, 1996-2012 was assessed with a panel of 1986 SNPs (Ozerov et al., 2016). Introgression changed the genetic composition of wild populations, increased genetic diversity and lowered genetic divergence. Highly diverged genome regions in an aquaculture strain (Saint John River) in comparison with its wild founder population (Tobique River, Canada) were identified with a 6K SNP array (Liu et al., 2017b). Some outlier loci at these regions were near QTL for growth, appetite, maturity, or disease resistance, which exhibited the effects of strong artificial selection in hatchery stocks. In order to develop a high-density SNP, taking genome duplication and across-continent genetic variation of complex traits in Atlantic salmon into account, de novo SNP discovery and validation was performed using specimens from Chilean, European and North American populations, including fish from wild and farmed origins (Yáñez et al., 2016). A 200K SNPs array can be used for assessment of gene flow from farmed stocks to wild salmon populations worldwide.

Temporal changes in the genetic structure of the threatened wild Atlantic salmon Magaguadavic River population, Bay of Fundy, Canada was studied using 112 SNPs (Bourret et al., 2011). A substantial decline in numbers of returning fish over the last two decades was noted. Wild and farmed individuals caught entering the river in 1980-2005, were genotyped. SNP genome scans identified a temporal decrease in candidate loci potentially under directional selection. This was indicated that farmed escapees had introgressed with wild Magaguadavic salmon resulting in significant change in the genetic integrity of the native population, including possible loss of adaptation to wild conditions. Historical and contemporary samples from 20 populations in Norway were genotyped with a panel of SNP markers differentiating farmed and wild Atlantic salmon (Glover et al., 2013). Five populations exhibited significant temporal genetic changes and became more similar to a pool of farmed fish with time, strongly suggesting introgression from escaped farmed fish. The remaining 15 populations displayed weak or non-significant temporal genetic changes. The amongpopulation level of divergence decreased with time. The level of cumulative introgression has been population-specific, and was not solely dependent on the frequency of escapees observed in the population. It has been suggested that such demographic processes in the native population as spawning success and survival of the offspring influence the relative success of farmed salmon in the wild (Heino et al., 2015). Hatchery released and native extirpated salmon populations were identified in Poland using an Atlantic salmon array (Pocwierz-Kotus et al., 2015; Bernas et al., 2016). Understanding of the hybridization dynamics between wild salmon and aquaculture escapees requires discrimination of different hybrid classes (Pritchard et al., 2016). Using the Atlantic salmon array, a set of 200 SNPs differentiating an Atlantic salmon stock from Teno River, Norway and escapees was identified. Both the complete set of SNPs and smaller subsets 
could reliably assign individuals to different hybrid classes up to the third hybrid (F3) generation.

Analysis of 3781 SNP markers from Salmo trutta SNParray, in wild and hatchery populations of brown trout from the Lake Savalen, Norway demonstrated significant genetic differences related to human-mediated and natural selection in growth, an important fitness-related trait (Linlokken et al., 2017). An Atlantic salmon derived SNP-array was also used for the genotyping of two populations of Southern Baltic Sea trout $S$. trutta $\mathrm{m}$. trutta and a diagnostic panel of 39 SNPs was selected for further population genetic analyses and identification of changes related to stocking (Drywa et al., 2013; Pocwierz-Kotus et al., 2014; Wenne et al., 2016b, Wenne et al., 2016c). Large numbers of SNP markers obtained with NGS was used for genome-wide diversity assessment of wild Mediterranean brown trout $S$. trutta populations and from Atlantic and Mediterranean hatchery-reared strains in southern France that had used for stocking (Leitwein et al., 2016). Reduced polymorphism and pronounced heterozygote deficiency in hatchery strains compared to wild populations was found, which implied negative effects of stocking in wild populations. However, studies of genetic structure and diversity of populations of Chum Salmon Oncorhynchus keta using 52 SNP markers revealed eight regional groups, indicating the persistence of the historical genetic structure in extant populations in Japan despite the execution of a hatchery program for about 120 years (Sato et al., 2014).

Application of GBS allowed for the identification of 4275 SNP loci of blue catfish, Ictalurus furcatus, of which a multiplex of 64 SNPs was used for genotyping (Li et al., 2014). An admixture was observed between native and culture populations. A total of 5243 high-quality SNP markers was detected with NGS technique in marine bivalve, the black-lip pearl oyster Pinctada margaritifera from Fiji Islands (Lal et al., 2016). Significant population genetic differentiation, including outliers, was found among 3 wild populations and evidence of a genetic bottleneck in the hatchery population. No differences between wild populations from Japan and cultured stocks in China of Sea Cucumber, Apostichopus japonicas were found using 51 SNPs (Dong et al., 2016).

\section{Linkage maps}

Linkage maps show positions of genetic markers on chromosomes. The large number of SNP discovered and the development of SNP array enabled the construction of high density maps, such as for Atlantic salmon (S. salar) using up to 96000 SNP (Houston et al., 2014; Tsai et al., 2016b) and, rainbow trout (Rexroad et al., 2008; Palti et al., 2015a). Linkage maps for male and female Atlantic salmon were constructed based on SNPs (Moen et al., 2008; Lien et al., 2011; Gonen et al., 2014). Differences between male and female recombination rate were assessed. The linkage map was helpful in physical mapping of the salmon genome. An integrated linkage map for Chinook salmon (Oncorhynchus tshawytscha) using 14620 SNP loci mapped, 286 salmon scaffolds, and 11728 ESTs were created (McKinney et al., 2016). Genome regions with increased divergence between populations were found, and candidate fitness related genes such as stress response, growth and behavior were identified.
Thermotolerance QTL co-occurred with several candidate genes including HSP70.

A high-density genetic linkage map was generated for channel catfish, Ictalurus punctatus and integrated with a physical map by application of genotyping of families with the 250K SNP array (Liu et al., 2011; Li et al., 2015). Over 50000 SNPs were placed on this linkage map, which covered $90 \%$ (867) $\mathrm{Mb}$ of the catfish genome. The estimated genetic size was $3505.4 \mathrm{cM}$ and a resolution of $0.22 \mathrm{cM}$ for the sexaveraged genetic map. The integrated map facilitated the catfish genome assembly, QTL mapping and positional cloning of genes responsible for economically useful traits. A highdensity interspecific genetic linkage map for hybrid channel catfish (I. punctatus) and blue catfish (I. furcatus) was also constructed (Liu et al., 2016). Over 26000 SNPs were mapped to 29 linkage groups. Less than a thousand revealed significant deviation from the expected Mendelian ratio and were grouped in 2 major genomic blocks. Strong selection against the blue catfish female alleles was suggested as an explanation.

A genetic map for common carp (Cyprinus carpio) was constructed with 8487 SNP markers from gene coverage 50 linkage groups and spanning $3762.88 \mathrm{cM}$ (Laghari et al., 2014; $\mathrm{Xu}$ et al., 2014; Liu et al., 2017a). 217 microsatellites and 336 SNP markers were selected to analyze the genomic DNA of 68 individuals derived from a group of F2 hybrids of mirror carp, C. carpio ( $\mathrm{Li}$ et al., 2011). A genetic linkage map was constructed and 14 QTL were identified for body weight. A backcross common carp family, with 86 progeny, was used to construct a genetic map for preliminary QTL mapping. Fourteen QTL associated with body weight, body length and condition factor were detected on ten linkage groups. For common carp, a total of 978 microsatellite and 3899 SNP markers were assigned to construct the genetic map, which comprised 50 linkage groups (Jin et al., 2015a). Ten QTL were found to be associated with eye diameter and twenty QTL were found to be related to eye cross. A dense SNP-based linkage map was constructed using interspecific cross between two closely related cyprinid species in Japan: river-dwelling Gnathopogon elongatus and lake-dwelling G. caerulescens (Kakioka et al., 2013). Based on 1622 RAD-tag markers, a linkage map spanned $1390.9 \mathrm{cM}$ with average marker distance of $0.87 \mathrm{cM}$. High-density genetic linkage maps for orangespotted grouper Epinephelus coioides were generated using multiplexed shotgun genotyping method (You et al., 2013). The sex-averaged map contained a total of 4608 SNPs, which covered $1581.7 \mathrm{cM}$, with average distance between SNPs of $0.34 \mathrm{cM}$. Physical and linkage maps for yellowtail (Seriola quinqueradiata), an important species in fish aquaculture in Japan was constructed using SNP obtained from NGS results and synteny with four model fish species was analyzed (Aoki et al., 2015). A double digest RAD (ddRAD)-based genetic linkage map was generated for the Japanese eel Anguilla japonica (Kai et al., 2014). The map for female spanned $1748.8 \mathrm{cM}$, whereas the map span for males was $1294.5 \mathrm{cM}$. A total of 2672 SNP markers provided anchor points to 1252 scaffolds covering $151 \mathrm{Mb}$.

Genetic linkage maps were constructed also for some other species important for aquaculture, as gilthead sea bream, Sparus aurata (Tsigenopoulos et al., 2014); Asian seabass, Lates calcarifer (Wang et al., 2015a; Sun et al., 2017); mandarin fish, Siniperca chuatsi(Sun et al., 2017); turbot, 
Scophthalmus maximus(Wang et al., 2015b); Japanese flounder, Paralichthys olivaceus (Castaño-Sánchez et al., 2010; Shao et al., 2015); large yellow croaker, Larimichthys crocea (Ao et al., 2015); black tiger shrimp, Penaeus monodon (Baranski et al., 2014); Pacific white shrimp, L. annamei (Du et al., 2010); Pacific abalone, Haliotis discus hannai (Qi et al., 2010); South African abalone, Haliotis midae (Vervalle et al., 2013) and silver-lipped pearl oyster, Pinctada maxima (Jones et al., 2013). Linkage maps of commercial fish and shellfish have been listed in other review papers (Wenne et al., 2007; Yue, 2014; Abdelrahman et al., 2017).

\section{Growth traits}

Growth is the most economically important trait in many selection programs in aquaculture, therefore there have been numerous studies on the subject. The source populations used for creation of aquaculture stocks differ in their ecological characteristics. European and North American lineages of Atlantic salmon ( $S$. salar) differ in phenotypic characteristics, including rate of growth. In order to understand genetic background of these differences, large $(N=300)$ backcross families were created and were genotyped for 129 SNPs (Boulding et al., 2008). 79 significant associations were found between SNP markers and quantitative traits including QTL for parr growth and condition index linked to the sexdetermining locus. Genetic mapping of QTL for body-weight in Atlantic salmon in a Mainstream Canada broodstock program was performed using a $6.5 \mathrm{~K}$ SNP array (Gutierrez et al., 2012). Parents and progeny were genotyped. Genomewide significant QTL $(\alpha=0.05)$ was linked to 6 chromosomes, QTL $(\alpha=0.01)$ to several chromosomes and a suggestive QTL $(\alpha=0.05)$ associated with body-weight was identified. These QTL were suggested as candidates for use in marker-assisted selection. GWAS for growth traits was performed in juvenile Atlantic salmon farmed in Scotland, UK, using a high density, 132K SNP array (Tsai et al., 2015c). After quality check, the results of genotyping of 622 fish (534 offspring, 28 sires and 60 dams) with 111908 SNPs were chosen for the analyses. The heritability for weight and length traits was 0.5 and 0.6 respectively. Both traits were polygenic. There was little effect QTL on a few chromosomes. A possible positional candidate gene could be a SNP in the retinoic acid-induced protein 2 gene on chromosome 17. However, SNP associations found in more than one population are more likely to be reflecting real QTL in salmon (Tsai et al., 2015b).

A significant association between a SNP allele and early growth in Arctic charr, Salvelinus alpinus, in Canada was found for the locus containing the growth hormone-releasing hormone and pituitary adenylate cyclase-activating polypeptide genes (GHRH/PACAP2) (Tao and Boulding, 2003). SNP markers located in candidate genes involved in growth were detected in turbot by integrating next generation sequencing and growthrelated QTL mapping (Robledo et al., 2016). Muscle and liver transcriptome from 18 individuals was sequenced and a total of 20447 genes and 85344 SNPs were found. Forty-three SNPs on growth-related genes were selected based on QTL co-localization in a wild Atlantic population. SNPs in growth hormone gene of large yellow croaker L. crocea was correlated with growth traits (Ni et al., 2012).
High-throughput GBS was used to detect and map a few thousand SNPs in haploid Chinook salmon, O. tshawytscha (Everett and Seeb, 2014). This map was used to detect QTL related to temperature tolerance and body size in families of diploid Chinook salmon. 3534 SNPs in 34 linkage groups were mapped. Four QTL for temperature tolerance and one QTL for body size were detected. A linkage map for brook charr (Salvelinus fontinalis) in Canada consisted of 266 SNPs and 81 microsatellites (Sauvage et al., 2012). Sixty-four growthrelated and 4 stress-related QTL were found across 18 of the 40 linkage groups. QTL of little-effect and a larger effect were identified. QTL for growth were found in F2 generation of crossed wild specimens of the Asian seabass (barramundi) $L$. calcarifer originating from 4 countries Thailand, Indonesia, Malaysia and Singapore (Xia et al., 2013). For individuals kept in one tank and differing in growth, SNPs in candidate genes were genotyped using sequencing. Twenty one significant QTL were identified. QTL mapping revealed a SNP associated with growth in the intestinal fatty acid (FA) binding protein (IFABP-a) gene. NGS of transcriptome from fast and slow growing largemouth bass Micropterus salmoides showed that a few metabolic pathways could be associated with muscle growth (Li et al., 2017b). Putative SNPs were selected and genotyping of 17 SNPs in 340 individuals revealed three SNPs associated with growth in genes: phosphoenolpyruvate carboxykinase 1, FOXO3b, and heat shock protein beta-1.

Twenty-two SNPs were identified as associated with growth in 778 individuals representing 40 families of rainbow trout using RNA-Seq whole-transcriptome (Salem et al., 2012). A group of female fish selected for improved growth and unselected genetic cohorts (10 fish from 1 full-sib family each) were compared and allelic imbalances were identified. Some SNPs were clustered into genes of metabolic energy production pathways and were considered suitable candidates for genetic selection. Transcriptome profiles were compared between fast and slow-growing rainbow trout across seasonal gradients (Danzmann et al., 2016). Slow-growing fish had elevated creatine kinase, TSC2 n and p53 expression levels. Large fish displayed a reaction similar to resistance physiology with elevated cytoskeletal gene component expression and glycogen metabolism cycling along with higher PI3K levels as well as lipid metabolic gene expression elevated, in particular the G0S2 switch gene. Twenty-three out of 26 gene families with previously reported significant SNP-based growth differences were confirmed as having significant expression differences. However, seasonal changes in gene expression were greater than differences associated with fish size.

In studies of aquacultured invertebrates, a high-resolution genetic linkage mapand QTL identification were performed using the RAD technology in the Kuruma prawn, Marsupenaeus japonicas ( $\mathrm{Lu}$ et al., 2016). QTL, 129 for hightemperature tolerance overlapped with linked SNPs, and 4 growth-related were located in regions between contiguous SNPs. Twenty eight SNP markers at 23 candidate genes potentially associated with growth were found in an improved giant freshwater prawn, Macrobrachium rosenbergii culture line in Vietnam (Jung et al., 2014). SNP polymorphism at vitellogenin receptor (PmVtgr) associated with reproductionrelated phenotypes (gonadosomatic index and ovarian weight) of the giant tiger shrimp P. monodon were found (Klinbunga et al., 2015). The expression of X-box binding protein 1 
(PmXbp1) during ovarian development in wild P. monodon broodstock and association between its SNP and growthrelated parameters were observed: expression of genotype A (corresponding to a T/T349 SNP) was significantly greater than that of juveniles carrying pattern $\mathrm{B}$ (corresponding to a $\mathrm{T} /$ C349 SNP) (Prasertlux et al., 2015). The growth-related genes were screened using paired-end sequencing technology in the swimming crab Portunus trituberculatus in China (Lv et al., 2015b). One growth-associated SNP was identified, which was located in hemocyanin as a result of association analysis.

A SNP associated with scallop growth for both the shell and soft body was identified in the insulin-like growth factor binding proteins IGFBP gene in a bivalve, Yesso scallop, Patinopecten yessoensis (Feng et al., 2014). A SNP in the 3' UTR (c. $1815 \mathrm{C}>\mathrm{T}$ ) of the transforming growth factor beta (TGF-beta) gene was potentially negatively associated with both scallop Chlamys farreri growth and Tgfbr1 expression (Guo et al., 2012).

\section{Sex determination in fish}

Sex determination systems are extremely diverse in fish. In many species, sex can be reversed during the course of a life and can depend on environmental conditions and social interactions. Females and males can differ in growth rate, which has implications for aquaculture. Sex manipulation is commonly practiced in aquaculture for example in Nile tilapia, Oreochromis niloticus (Mair et al., 1991; Garcia et al., 2016; Sansuwan et al., 2017), (Calhoun and Shelton, 1983), gilthead sea bream, S. aurata (Loukovitis et al., 2012), European sea bass, Dicentrarchus labrax (Martinez et al., 2014) and turbot, S. maximus (Robledo et al., 2015). Early sexual maturation (grilsing) retards growth, increases production times and affects flesh quality in aquaculture. A 6.5K SNP array was used to genotype approximately 3300 fishes from the Atlantic salmon, S. salar Cermaq (Mainstream) Canada broodstock program (Gutierrez et al., 2015). The analysis of results revealed identification markers showing a significant association with growth, grilsing and late sexual maturation. Candidate genes linked to these genetic markers, were identified and some were connected with developmental processes. In order to overcome problems associated with early sexual maturation as in males in Tasmanian Atlantic salmon, sex-reversed females have been crossed with normal females to produce all female stock (Eisbrenner et al., 2014). The results of a TaqMan 64 SNP genome-wide scan indicated that the sex-determining gene in two Scottish Atlantic salmon families was positioned on chromosome 6 , but in lineages in the SALTAS breeding program of Canadian origin this gene was found to be located at three loci. This confirmed genomic differences between different geographic lineages of salmon populations.

Twenty-six gene families involved in reproduction and sex determination were identified from testicular and ovarian transcriptomes and a number of SNP markers for further study were discovered in Amur sturgeon, Acipenser schrenckii (Jin et al., 2015b). The wreckfish hapuku (Polyprion oxygeneios) is not externally sexually dimorphic and need over 5 years to reach sexual maturity in captivity, this hinders broodstock management (Brown et al., 2016). Combined and sex-specific linkage maps were constructed based on 1575 SNP markers. A major sex-determining locus, heterogametic in males, and several markers in strong linkage disequilibrium were mapped. PCR assays were developed for two of these markers. In the rock bream Oplegnathus fasciatus, sequence analysis revealed 19 male-specific SNPs, which enabled the development of 3 SNP markers (Xu et al., 2013). Mapping the sex determination locus in the Atlantic halibut (Hippoglossus hippoglossus) using sequencing was performed (Palaiokostas et al., 2013a). A linkage map was constructed based on 5703 SNP markers and 7 microsatellites creating 24 linkage groups, equivalent to chromosome pairs in this species. A major sex determining locus was mapped to linkage group 13. Ten SNPs with significant association with phenotypic sex were tested with 97\% success rate. Sex-associated DNA markers to fast track progeny testing will help to implement monosex female halibut production for an immediate improvement in productivity.

A high-density SNP based linkage map for European sea bass (D. labrax) was constructed with 6706 SNPs on 24 linkage groups, and putative sex-determining QTL were detected in 4 groups (Palaiokostas et al., 2015). The polygenic sex determination hypothesis in sea bass was confirmed. A linkage map with 3280 informative SNP markers was constructed, and a major sex-determining region in Nile tilapia, O. niloticus was identified explaining almost $96 \%$ of the phenotypic variance (Palaiokostas et al., 2013b). For 2 SNPs showing the highest association, in family and population data, all females were homozygous whereas males were heterozygous with 7 exceptions. These few male fish exceptions possessed the homozygous genotype expected of females - XX males. Appearance of sex reversal can be caused by elevated temperature. In aquaculture of half-smooth tongue sole, Cynoglossus semilaevis, some female fish reverse to pseudomales, which increases maintenance costs due to lower growth rate of males (Jiang and Li, 2017). A polymorphic SNP correlated with sex reversal was found. Genetic females with this SNP's allele A do not reverse into phenotypic males. Unraveling thesex reversal mechanisms can substantially improve female ratio in management of aquacultured stocks. Production of monosex female stocks is beneficial for commercial purposes since females grow faster and mature later than males. Developing sex-associated markers can shorten the time of monosex female production and decrease the costs of farming.

\section{Resistance to pathogens}

Similarly to other agricultural activities, aquaculture causes epidemiological threats and can enhance invasions of pathogens in natural waters and to new geographic areas. SNP analysis in salmonid bacterial pathogen Renibacterium salmoninarum causing kidney disease showed its intercontinental propagation associated with fish movements (Brynildsrud et al., 2014). The identified closely-related isolates linked to neighboring fish farms, most probably formed part of single outbreaks. It was demonstrated that a subgroup of $R$. salmoninarum isolated from Norway and the UK represented an introduction to these areas $\sim 40$ years ago. This example demonstrated the promise of SNP genotyping technology for 
analysis of genetic relationships in veterinary and environmental microorganisms. A comparison of genome regions in Vibrio harveyi and related species with the shrimp pathogen $V$. harveyi (CAIM 1792) demonstrated its higher similarity to those of other $V$. harveyi strains than to those of the other closely related species $V$. owensii, $V$. rotiferianus and $V$. campbellii (Espinoza-Valles et al., 2015). The SNP trees showed that $V$. harveyi is the most conserved of the four species studied, and $V$. campbellii may be divided into at least three subspecies. SNPs have been used in studies of other fish pathogens, as salmon louse Caligus rogercresseyi (Copepoda: Caligidae). High-throughput SNP discovery and transcriptome expression profiles of $C$. rogercresseyi lead to the identification of pathways involved in resistance to antiparasitic agents, which is highly useful for investigating the susceptibility or resistance to chemical treatments (Nunez-Acuna et al., 2014). A genomic region strongly linked to pesticide emamectin benzoate resistance was defined in salmon louse using SNParray (Besnier et al., 2014). A spread of this resistance was human-induced. Atlantic salmon introduced to aquaculture in Chile turned out to be susceptible to bacterial pathogen Streptococcus phocae subsp. salmonis, whereas rainbow trout was resistant (Salazar et al., 2016). Diseases have caused great losses in the aquaculture industry and substantial efforts have been undertaken with the aim to reduce susceptibility of farmed animals and prevent the spread of pathogens.

\section{Viral diseases}

Viral diseases are an important threat to the fish farming industry. The genetic background of resistance to some viral diseases have been reported in fish (Moen, 2010). Fifty segregating SNP markers linked to a major QTL were found to affect resistance to infectious pancreatic necrosis virus (IPNV) in pedigreed Atlantic salmon ( $S$. salar) from a commercial breeding program in Scotland using RAD-sequencing (Houston et al., 2012). A QTL in Norwegian salmon for IPNV resistance was initially identified with microsatellite markers (Moen et al., 2009). This QTL has been employed in markerassisted selection in two breeding companies in Norway and Scotland, which resulted in $75 \%$ reduction in the number of IPN-outbreaks (Moen, 2010; Moen et al., 2015). This QTL has been located on the SNP-based linkage map and identified as the epithelial cadherin $(c d h l)$ gene. A SNP was found within the $c d h 1-1$ gene as the significant determinant of the resistance of Atlantic salmon individuals to IPNV. A functional involvement of epithelial cadherin protein in internalization of the IPNV was reported for the first time, as similar to bacteria and fungi. The resistance and susceptibility to grass carp reovirus (GCRV) in individuals and cell lines was associated with SNPs identified by comparative transcriptome analysis (Liao et al., 2017). GBS revealed SNPs associated with viral nervous necrosis disease (VNN) in Asian seabass (Wang et al., 2017).

In order to find SNPs useful for breeding common carp $(C$. carpio) resistant to disease caused by cyprinid herpesvirus 3 (CyHV-3), 11 candidate genes were amplified and sequenced (Kongchum et al., 2010). The utility of the identified SNP markers was evaluated in one full-sib family and results revealed that 20 markers from 9 loci segregated in a disomic and Mendelian pattern and would be applicable for linkage analysis. Infectious diseases such as koi herpesvirus (KHV) and Aeromonas hydrophila have caused world-wide massive mortality of common carp. Differential resistance to these diseases has been observed and programs for common carp genetic resistance and improvement of survival rates are needed in aquaculture. Interleukin-1b (IL-1b) is a key component in innate immunity and the inflammatory response. SNP variation was found at 13 positions of the interleukin-1 $\beta$ gene of bighead carp (C. pellegrini) and five strains of common carp (C. carpio) in China and can be helpful in understanding resistance to these diseases (Jia et al., 2015).

\section{Bacterial diseases}

Bacterial cold water disease (BCWD) induces mortality in many salmonid farms. In order to identify SNP markers associated with resistance to this disease and spleen size in rainbow trout in Leetown, West Virginia, USA a total of 298 offspring from the two half-sib families challenged with bacteria Flavobacterium psychrophilum were genotyped with Restriction-Site Associated DNA Sequencing (RAD-seq) (Liu et al., 2015b). Using GWAS, 18 SNPs associated with resistance to the BCWD and 20 SNPs associated with spleen size were identified. Linkage-based QTL mapping revealed three significant QTL for the BCWD resistance. The SNP markers facilitated fine mapping to identify positional candidate genes for BCWD resistance in rainbow trout. Selective genotyping of SNPs from $S b f$ RAD associated DNA sequencing data were used to validate major QTL affecting BCWD resistance already detected in two families of rainbow trout, to increase density of markers in the QTL regions and to detect new QTL thanks to the higher marker density of the genome scan. Some QTL previously detected in microsatellite scans were validated and new QTL were found with SNPs using selective genotyping of SNPs from $S b f$ I RAD associated DNA sequencing data (Palti et al., 2015b). Location of candidate genes in the vicinity of two Omy8 QTL may suggest the existence of potential linkages between immune and stress responses in rainbow trout. The identified OTL can be useful for marker assisted selection. Another important bacterial disease affecting salmonids is piscirickettsiosis. 2601 Atlantic salmon ( $S$. salar) smolts, the progeny of 40 sires and 118 dams from a breeding population in Chile were experimentally challenged with Piscirickettsia salmonis by means of intraperitoneal injection and genotyped with a 50K SNP array (Correa et al., 2015). Candidate genes including interleukin receptors and fucosyltransferase were found to be physically linked with the 5 SNPs significantly associated with the resistance trait.

Leukocyte cell-derived chemotaxin-2 (LECT2) is an important protein of the innate immune system for defense against bacterial infection. LECT2 gene was cloned, characterized, and its expression in response to a challenge with a pathogenic bacteria $V$. harveyi was studied in tissues of Asian seabass, L. calcarifer (Fu et al., 2014a). The LECT2 transcript was up-regulated in the kidney, spleen and liver. Three SNPs in the LECT2 gene were found to be associated with resistance to the big belly disease of Asian seabass and may be useful for selection programme in aquaculture. Enteric septicemia of 
channel catfish (ESC) is caused by bacteria Edwardsiella ictaluri. Genotyping of several hundred fish with the catfish 250K SNP array was undertaken and was helpful in identification of genomic regions associated with ESC disease resistance (Zhou et al., 2017). Several QTL associated with resistance to ESC were identified. A SNP associated with the $n c k 1$ gene, upregulated after ESC challenge was found.

Nine QTLs formed two main clusters for Vibrio anguillarum disease resistance of Japanese flounder ( $P$. olivaceus) from Yantai, China (Shao et al., 2015). Synteny analysis of the QTL regions on the genome assembly revealed 12 immune-related genes including 4 strongly associated with disease resistance. The lipopolysaccharide-binding protein (LBP) gene is involved in the acute-phase immunologic response to bacterial infections. Its expression was differentiated in response to challenges of Mozambique tilapia Oreochromis mossambicus from Singapore, with two bacterial pathogens Streptcoccus agalactiae and Aeromonas hydrophila (Fu et al., 2014b). Associations were found in two SNPs at the LBP gene with the resistance to A. hydrophila. The mast cell protease 8 (MCP-8) gene expression was enhanced in intestine, kidney, spleen and liver in tilapia, after a challenge, and three SNPs identified in the MCP-8 gene were significantly associated with resistance to $S$. agalactiae ( $\mathrm{Fu}$ et al., 2014c). These SNP markers may facilitate selection of tilapia resistant to the bacterial disease. After a challenge with the same bacterial pathogen, expression of duodenase- 1 gene was up-regulated significantly in the intestine, liver and spleen in hybrid tilapia, Oreochromis spp. (Shen et al., 2015). Four SNPs were significantly associated with the resistance to $S$. agalactiae. One SNP was associated with growth traits. After a challenge, the expressions of the two genes Gadd45a1 (growth arrest and DNA damage $45 \mathrm{~A}$ ) and Gadd45a2 were upregulated in the spleen, kidney, liver and intestine (Shen et al., 2016a). The two Gadd45a genes may play an important role in resistance to $S$. agalactiae. Ten SNP markers were identified in the two Gadd45a genesin tilapia. A resource stock of grass carp was constructed consisting of specimens susceptible and resistant to hemorrhagic septicemia caused by $A$. hydrophila (Shen et al., 2016b). In the complement component C7 gene, 6 SNPs were found and the $425 \mathrm{C}>\mathrm{T}$ polymorphism may be a significant molecular marker for resistance to A. hydrophila. A TLR22 homologue gene was identified and characterized from grass carp Ctenopharyngodon idella (Su et al., 2012). Its expression in the spleen was significantly up-regulated postinjection of grass carp reovirus (GCRV). Six SNPs were detected in the gene sequence, butonly $417 \mathrm{G} / \mathrm{T}$ was significantly associated with the resistance of grass carp to GCRV.

Nine SNPs were discovered through direct sequencing of newly characterized interferon regulatory factor 2 gene from resistant and susceptible to Aeromonas hydrophilastock of freshwater mussel Hyriopsis cumingii (Wang et al., 2013). Only one SNP was significantly associated with resistance/ susceptibility. The distribution of three SNPs in C-type lectin gene (CTL) in susceptible and resistant stocks of the swimming crab P. trituberculatus was identified, according to the survival time after Vibrio alginolyticus challenge (Hao et al., 2015). The non-synonymous SNP E4-205C/T, C to T transition resulting in a Threonine to Isoleucine substitution at position 152 in the peptide of CTL protein, showed significant difference between the two stocks. The T/T genotype was shown to be associated with increased resistance. In the antilipopolysaccharide factor gene, sixteen SNPs were significantly associated with resistance/susceptibilityof the swimming crab to $V$. alginolyticus of which most were located in introns and noncoding exons, while two synonymous and one nonsynonymous SNP were in coding exons (Li et al., 2013a). Toll gene expression in green mud crab, Scylla paramamosain was up-regulated after infection with $V$. parahemolyticus (Lin et al., 2012). Two hundred and twenty SNPs in the leucine-rich repeats (LRRs) domain were found including one SNP c. $1372 \mathrm{~A}>\mathrm{G}$ with potential pathogen-resistant activities. To study crab Eriocheir sinensis immunogenetics, newly hatched larvae were experimentally challenged with a mixture of three pathogens: Gram-positive bacteria Micrococcus luteus, Gramnegative bacteria $V$. alginolyticus and fungi Pichia pastoris (Cui et al., 2013). Numerous genes identified in transcriptome were associated with immune pathways: Toll, immune deficiency, janus kinase-signal transducers and activators of transcription and mitogen-activated protein kinase, tumor necrosis factor receptor associated factor 6 (TRAF6), fibroblast growth factor, protein-tyrosine phosphatase and JNK-interacting protein 1 (JIP1). A cathepsin B gene of the Chinese shrimp Fenneropenaeus chinensis was characterized (Li et al., 2013b). A challenge test revealed the responses of FcCB in different tissues to white spot syndrome virus (WSSV) infection. The FcCB gene expressions after WSSV challenge in the gill, hepatopancreas and muscle was upregulated, suggesting that $\mathrm{FCCB}$ might be involved in the immune response. Three SNPs were identified involving $\mathrm{C} / \mathrm{T}$ transitions. A SNP genotype distribution in resistant and susceptible shrimps was obtained using a high-resolution melting method. However, no differences were observed in thefrequency of genotype C-984T between the two groups.

A genetic basis of monogenean fluke ectoparasite Benedenia seriolae disease resistance in yellowtail (Seriola uinqueradiata) was studied by using the linkage map with microsatellite and 142 SNP markers (Ozaki et al., 2013). Two QTL regions were found that contributed to Benedenia disease resistance.

\section{Stress response}

The quality of aquaculture production and fish welfare can be improved by the understanding of genetic fundamentals of stress responses. Twenty six SNP markers associated with cortisol response to crowding in rainbow trout were identified using GWAS (Liu et al., 2015a). Mapping revealed two QTL on chromosomes, of which a putative serine/threonine protein kinase gene was identified on Omy12. Its expression was changed in the liver in response to handling and under duress stress.

Hypoxia is an adversely operating environmental factor on fish survival, development and growth. To further understand molecular functions of an essential hypoxia sensor, Fih-1 was studied in a cyprinid fish, Wuchang bream Megalobram aamblycephala (Zhang et al., 2016). Three associated SNPs were found by correlation analysis in hypoxia-sensitive and hypoxia-tolerant groups. Six SNPs were detected in a cDNA sequence of a highly conserved and multifunctional 
endoplasmic reticulum chaperone (CRT) protein gene and one SNP was associated with the salt tolerant trait in fish $P$. trituberculatus (Lv et al., 2015a).

Studies of transferrin gene resulted in finding amino-acid changes in the coded protein caused by SNPs in surviving and non-surviving Nile tilapia ( $O$. niloticus) siblings kept in saltwater. An expression study indicated up-regulation of transferrin when tilapias were exposed to saltwater, which suggested its involvement in saltwater tolerance (Rengmark and Lingaas, 2007).

To study the molecular mechanism of cold tolerance, TCP1-eta homolog gene cDNA was obtained from Whiteleg shrimp Litopenaeus vannamei and was sequenced (Yin et al., 2011). TCP-1-eta gene expression depended on temperature. A SNP genotype was identified as significantly related to cold tolerance among individual shrimps. SNP identification by transcriptome sequencing and candidate gene-based association analysis was performed for heat tolerance in the bay scallop Argopecten irradians (Du et al., 2014). SNP all53308-760 T/C showed a significant difference in allele frequency between the heat-susceptible and heat-resistant groups. A significand difference in allele frequency at this locus was also observed between natural populations. These results suggest that SNP all-53308-760 T/C may be related to the heat tolerance. The expression level of all-53308 was negatively correlated with heat tolerance of the bay scallop. SNP polymorphism in the promoter region of metallothionein 1 and heat shock protein 90 genes was reported as associated with heat tolerance of bay scallop Argopecten irradians (Yang et al., 2013; Yang et al., 2015).

\section{Domestication and Genomic Selection}

Domestication of most cultured fish is very weakly advanced in comparison with terrestrial farmed animals and can be accelerated by application of genomic selection. Selective breeding of Atlantic salmon has been carried out intensively in Norway since the 1970s (Gjedrem, 2012). The genetic differentiation between three domesticated strains of Atlantic salmon S. salar, and populations of their wild conspecifics in Canada and North Europe was found to be low. The domesticated strains also harbored similar levels of genetic diversity compared to their wild conspecifics (Makinen et al., 2015). In the study of the same strains of Atlantic salmon, ten genomic regions were indicated as exhibiting signs of directional selection (Vasemagi et al., 2012). Most of the identified candidate regions were small, up to a few centimorgans in the female Atlantic salmon linkage map. The Cermaq Atlantic salmon broodstock population ('Mowi' strain from Norway) farmed since the mid 1980s in British Columbia, Canada was compared with four wild populations from Norway using genotyping with a $6.5 \mathrm{~K}$ SNP array (Gutierrez et al., 2016). Forty four markers were identified as outliers, and were associated with molecular functions that could be related to selection for growth, response to pathogens and environmental stressors, and with an undesirable early sexual maturation - grilsing trait, that is economically important traits and domestication. A 200K SNP custom array can be applied for carrying genomic selection in breeding programmes and genetic studies in wild populations (Yáñez et al., 2016). An Atlantic salmon 15K SNP chip was evaluated as a potential genomic tool for application in a Tasmanian Atlantic salmon (S. salar) breeding population and was found useful for carrying within-family selection (Dominik et al., 2010). Genetic diversity and frequencies of alleles in Tasmanian Atlantic salmon was lower than observed within European populations as revealed by analysis with 218132 SNPs array (Kijas et al., 2016). In contrast to the European Atlantic salmon, the strength of observed LD was high at short distances and remained above background for marker pairs separated by chromosomal distances of hundreds of $\mathrm{kb}$.

A large number of SNPs identified withNGS were used for analysis of domestication and artificial selection effects at the genome level by identification of the signatures of selection in channel catfish, I. punctatus in North America (Sun et al., 2014). One SNP per $116 \mathrm{bp}$ was found in the channel catfish genome. The domestic and wild populations differed in allele frequencies at 407861 SNPs. Eleven genes in 23 genomic regions with putative selective sweeps (excess of homozygosity) were found in analysis of annotations of these SNPs against the genetic map. Genes with known function related to aquaculture performance of traits under selection were identified, among them hypoxia-inducible factor 1-beta (HIF-1b) important for response and tolerance to low oxygen levels, the transporter gene ATP-binding cassette sub-family B member 5 (ABCB5). The reference catfish genome has been published (Liu et al., 2016). The identified large number of SNPs was used for 250K SNPs mapping on the linkage map and development of high-density (690K) SNP arrays for genomic studies of cultured traits in catfish (Zeng et al., 2017).

Response to selection at the genomic level was also studied in invertebrates, including the second generation of a breeding programme of blue mussel (Mytilus galloprovincialis) in Australia (Nguyen et al., 2014). To assist the reconstruction of a pedigree from families, a panel of 179 SNPs was developed. In the second generation, heritability of total weight, shape and meat yield were estimated. The selection response was up to $10 \%$, indicating that further genetic gains can be achieved through a family-based breeding programme. Recently, SNPs have been used also in studies of Mytilus from other geographic regions (Kijewski et al., 2009; Vera et al., 2010; Zbawicka et al., 2012; Wennerstrom et al., 2013; Zbawicka et al., 2014; Pino-Querido et al., 2015; Wenne et al., 2016a; Jilberto et al., 2017).

GS can considerably increase genetic gain in traits of interest and is suitable for analysis of polygenic traits. GS can be used to enhance existing salmon-breeding family-based schemes by incorporation of within family breeding values estimated with low density genotyping (Lillehammer et al., 2013). Alternatively to QTL and between-family genetic variation, due to the complex genetic architecture, application of a whole genome-enabled selection turned out to be a better strategy for improving rainbow trout genetic resistance against BCWD (Vallejo et al., 2016). GS was based on using high-density SNP genotype data and phenotypic records in order to compute genomic estimated breeding values (GEBVs). Individual fish representing 10 families from the first generation of the National Center for Cool and Cold Water Aquaculture (NCCCWA, USA) BCWD resistant breeding line were genotyped with the rainbow trout 57K SNP array and using restriction-site associated DNA (RAD) sequencing. The RAD genotyping platform had similar 
predictive ability to GEBVs in comparison with those from the chip platform. A more thorough study of the farmed rainbow trout was carried out on larger number of specimens and full-sib families, and the GEBV based breeders mating design for progeny testing (Vallejo et al., 2017). The accuracy prediction of genomic-enabled breeding values from three GS models: singlestep genomic best linear unbiased prediction (ssGBLUP), weighted ssGBLUP (wssGBLUP), and BayesB was twice that of the P-BLUP model EBV. The proportion of the phenotypic variance explained by SNPs significantly associated with resistance to salmon rickettsial syndrome (SRS) caused by $P$. salmonis was found to be low (Correa et al., 2015). Therefore GS was used in further attempts to improve genetic resistance to SRS (Bangera et al., 2017). The GBLUP method for application in the GS evaluation and optimization of SNP density may reduce costs of genotyping.

Sea lice Lepeophtheirus salmonis and C. rogercresseyi are an ectoparasitic copepod infecting salmon and rainbow trout respectively in northern and southern hemispheres. In addition to inflicting substantial economic losses to farmed and wild fish, both species can be vectors for other pathogens. Resistance of Atlantic salmon to sea lice has been found as polygenic (Tsai et al., 2016a). A comparison of genomic selection methods was performed for $C$. rogercresseyi resistance based on genotyping with an SNP array (Correa et al., 2017). Atlantic salmon 2404 individuals from 118 families were challenged and genotyped using 37K SNPs. Prediction accuracy of EBV for C. rogercresseyi resistance increased with increasing density of SNPs selected from the panel used for genotyping. The accuracy prediction for at least 500 SNPs was higher than pedigree-based BLUP methods. The best results were obtained with 10K SNPs using G-BLUP and Bayesian methods.

\section{Traceability of aquaculture production}

The successful use of SNPs in the identification of species, populations, aquaculture stocks and parentage assignments has lead to their positive evaluation for traceability in fisheries and wildlife forensics (e.g. Atlantic cod Gadus morhua and sole Solea solea (Bylemans et al., 2016)), aquaculture (e.g. Atlantic salmon S. salar in Norway, (Hayes et al., 2005)), and sea and freshwater wild and farmed food products including caviar (e. g. sturgeon, Ogden et al., 2013). DNA markers can be used to trace aquaculture species as market products to farm of origin in case of disease or toxin detection. The Atlantic salmon industry involves 3 tiers: nucleus specimens, multiplier herd, and commercial fish. The number of SNPs required for correct assignment of market place fish to full sib families on a single farm was up to 400 , to multiplier individuals (parents) it was 74 and to nucleus individuals, was 200. SNPs have been used for species identification of food products as tuna (Kitaoka et al., 2008) and food product origin, including sturgeon caviar origin (Jenneckens et al., 2001; Ogden et al., 2013).

\section{Aquaculture food product quality analyses}

Aquaculture is a growing food production industry and the nutritional value of marine products, rich in micronutrients and containing high levels of $n-3$ FAs, compares favorably with meat from farm animals (Gjedrem et al., 2012). The quality of aquaculture products depends on harvest traits suchas body weight traits, flesh color and fat percentage and composition. In order to study the genetic basis for growth and fillet traits suchas weight and flesh color in farmed Atlantic salmon $(S$. salar), offspring with trait records were genotyped for the SNPs (Tsai et al., 2015a). Genome-wide significant QTL affecting several growth-related traits were identified on 4 chromosomes. The traits were polygenic and QTL affected the weight of several components of the harvested fish. Comparison of QTL regions in this and other studies suggests that harvest trait QTL is population-specific. Therefore, the application of marker or genomic selection for improvement in these traits can be more effective when the discovery population is closely related to the selection candidates, e.g. within-family genomic selection. In a study, it was found that a SNP variation in the $5^{\prime}$ flanking region of the myostatin gene can be associated with harvest trait (growth) in Atlantic salmon (Penaloza et al., 2013). An Atlantic salmon array containing 5650 genome-wide distributed SNPs was used to identify genetic variation affecting fillet fat content and fillet firmness traits in farmed Norwegian Atlantic salmon (Sodeland et al., 2013). Validation of results from GWAS was performed by estimation of variance components for chromosomes based on SNPs. Results from GWAS and genome partitioning suggested that genetic variation affecting fillet fat content is located on chromosomes 9 and 10, and that genetic variation affecting fillet firmness on chromosomes 3 and 11. An array with a larger number of SNPs (38 107) was used in GWAS analysis for fillet yield, body weight, head-off carcass weight, and fillet weight in a pedigreed rainbow trout stock selected for improved growth performance (Gonzalez-Pena et al., 2016). SNP polymorphism was studied for 875 fish from full-sib families in three generations. Panels of 20 adjacent SNPs were created and used in the GWAS analysis. A few panels were found to explain very low level of variance indicating a polygenic nature of the studied traits. A majority of the identified SNPs were mapped to genes, and the gene network was considered to be involved in differentiation of growth and fillet yield in rainbow trout. A genome-wide scan revealed 4 QTL affecting flesh fat content for common carp C. carpio (Kuang et al., 2015). Polymorphism of SNPs in the lipoprotein lipase, an enzyme which catalyzes the oxidation of triglycerides into glycerin and FA, was associated with 2 different feeding preferences of wild and aquacultured mandarin fish $S$. chuatsi, this can be helpful in further domestication processes (Yang et al., 2011).

Fish oils are the most common source of source of $n-F A s$ and their intake is negatively related to human cardiovascular disease risk (Fernandes et al., 2012; Tur et al., 2012). Marine organisms are a well established source of $n-3$ PUFA. The primary producers of lipids and FAs enriched with $n-3$ PUFA are bacteria, phytoplankton, algae and diatoms, which are grazed by zooplankton, pelagic and benthic animals, including filtrators such as marine bivalves and crustaceans, fish and marine mammals. Marine bivalve lipids have been well characterized (Baptista et al., 2014; Jarzebski et al., 1986a; Jarzebski and Wenne, 1990; Jarzebski et al., 1986b; Polak et al., 1987; Wenne and Polak, 1989; Wenne and StyczynskaJurewicz, 1987). Long-chain FA-CoA ligases (ACSLs) play crucial roles in FA metabolism. A significant increase in 
expression of ACSL1 level in a starvation experiment indicated its important role in metabolism and energy supply and storage in hepatopancreas in the clam Meretrix meretrix (Dai et al., 2015). Two exon SNPs and 6 intron SNPs were found in this gene by direct sequencing. Five of these SNPs and haplotypes were significantly associated with growth traits. Replacement fish meal and fish oil by soybean protein and algal meal from Schizochytrium limacinumin diets for giant grouper Epinephelus lanceolatus demonstrated that fillet FA profile of fish reflected dietary composition and was significantly affected by the lipid source (García-Ortega et al., 2016). However, possible association of SNPs with FA biosynthesis and composition have been reported for agriculture plants (Ben et al., 2017; Li et al., 2017a; Qu et al., 2017) and animals (Cosenza et al., 2017; van Son et al., 2017; Zhu et al., 2017), and very rarely in fish. A genome-wide scan for QTL affecting FA level in flesh (fillets), including $n-3$ polyunsaturated FAs (PUFA) was performed in an Asian seabass $L$. calcarifer F-2 family containing 314 offspring (Xia et al., 2014). High percentages of $n-3$ PUFA, especially C22:6 and C20:5 were observed in the flesh. All family members were genotyped using $22 \mathrm{SNPs}$, and microsatellites. QTL for total $\mathrm{n}-3$ PUFA content in flesh, QTL for C18:0b and C22:6 were found. EcoRI-NlaIII based GBS of a few hundred individuals of large yellow croaker $L$. crocea resulted in finding 69845 SNP markers distributed along the entire genome (Xiao et al., 2016). The association of 39 significant SNPs was found with the content of eicosapentaenoic acid and docosahexaenoic acid in the muscle. SNP markers were mapped to functional genes involved in lipid digestion, absorption, and metabolism, such as apolipoprotein B, carnitine O-acetyltrasferase, oxysterol binding protein 10 andpalmitoyl-protein thioesteraes 2 Gene.

\section{Conclusions}

Analysis of SNPs has emerged as a genotyping technology with wide and significant applications in aquaculture. SNPs can be used for construction of high-density and highresolution genetic linkage maps, finding QTL for useful traits like growth, body weight, morphological characters, grilsing, thermal and low oxygen tolerance, resistance to stress and diseases, mapping sex determination loci and identification of progeny in selection and chromosome manipulation experiments and assessment of genomic selectionin aquaculture. SNPs are used for identification of region-selective sweeps (containing genes) in the genome, which are related to useful traits for aquaculture. SNPs are useful also to identify genes, sequences and nucleotides (substitutions) directly influencing phenotypic variations, thus opening the possibility of marker assisted selection for desirable characters/traits in culture. If a sufficiently large number of SNPs is discovered and used, mutations in genes associated with a trait can be identified. The identified genotypes can be used in marker assisted selection. A large number of SNPs used in a study is feasible for analysis of polygenic (complex) traits and facilitates the finding of genotypes useful for aquaculture.

Re-sequencing of genomes of several individuals belonging to the same species gives the possibility to obtain from dozens of thousands to dozens of millions SNPs (Abdelrahman et al., 2017; Yue and Wang, 2017). However, this approach is still expensive and time-consuming. SNPs associated with traits of choice (phenotypes) can be identified by using complexity reduction strategies through NGS such as RNAseq, GBS (Elshire et al., 2011), multiplexed shotgun genotyping (Andolfatto et al., 2011) and restriction-site associated DNA sequencing (RAD-seq). Moreover, several RAD variants was developed with differences in the protocol: the original RAD (mbRAD) (Miller et al., 2007; Baird et al., 2008), ezRAD (Toonen et al., 2013), ddRAD (Peterson et al., 2012) and 2bRAD 2b-RAD (Wang et al., 2012); for details see review (Davey et al., 2013; Andrews et al., 2016). SNP genotyping can be performed on low or massive scale depending on the defined aims of research. Such methods as matrix-assisted laser desorption ionization time of flight (MALDI-TOF) mass spectrometry, Taqman allelic discrimination, real-time (quantitative) PCR and microarray or gene chips have been used in many studies related to aquaculture (Liu and Cordes, 2004). These methods have been improvedand their yield increased. Arrays with thousands or hundreds of thousands of SNPs have become a new high throughput genotyping tool. Usually, a large number of SNP loci is needed for evaluation of differences and changes in aquacultured stocks and estimation of genome wide linkage disequilibria. Strength of linkage disequilibria and genome size determine number of SNPs on array needed for GWAS and discovery of QTLs. Most of these assayed loci however are not informative, but it is now possible to identify several tens rather than hundreds of polymorphic and diagnostic SNP loci and subsequently use them for cost effective genotyping or few SNPs strongly associated with targeted economically useful trait. In case of complex traits, genomic selection is more feasible. Genotyping bygenome-reduction complexity sequencing can be recommended as an efficient and applicable technology in genomic selection.

In recent years, new methods of genetic engineering have been developed, which enable more precise characteristication and altering of gene function. Such technologies as zinc-finger nucleases, transcription activator-like effector nucleases and clustered, regularly interspaced, short palindromic repeats (CRISPR)-CRISPR-associated (Cas) systems (CRISPR/Cas9) have emerged as new tools for potential improvement of aquacultured fish (Cui et al., 2017; Li and Wang, 2017). The CRISPR/Cas9 gene editing technology has been used to generate lines of site directed mutated cell lines of Chinook salmon O. tshawytscha (Dehler et al., 2016) and can be used for determination of SNP function and QTL assessment (Macqueen et al., 2017). However, these technologies can be potentially used in highly developed large scale aquaculture systems.

Acknowledgements. This study was partially funded by project: 2011/01/M/NZ9/07207 of the National Science Centre in Poland to RW and statutory topic IV.1 in the IO PAS Sopot.

\section{References}

Abdelrahman H, ElHady M, Alcivar-Warren A, Allen S, Al-Tobasei $\mathrm{R}$, Bao L, Beck B, Blackburn H, Bosworth B, Buchanan J, Chappell J, Daniels W, Dong S, Dunham R, Durland E, Elaswad A, Gomez-Chiarri M, Gosh K, Guo X, Hackett P, Hanson T, 
Hedgecock D, Howard T, Holland L, Jackson M, Jin Y, Kahlil K, Kocher T, Leeds T, Li N, Lindsey L, Liu S, Liu Z, Martin K, Novriadi R, Odin R, Palti Y, Peatman E, Proestou D, Qin G, Reading B, Rexroad C, Roberts S, Salem M, Severin A, Shi H, Shoemaker C, Stiles S, Tan S, Tang KF, Thongda W, Tiersch T, Tomasso J, Prabowo WT, Vallejo R, van der Steen H, Vo K, Waldbieser G, Wang H, Wang X, Xiang J, Yang Y, Yant R, Yuan Z, Zeng Q, Zhou T. 2017. Aquaculture genomics, genetics and breeding in the United States: current status, challenges, and priorities for future research. BMC Genomics 18: 191.

Andolfatto P, Davison D, Erezyilmaz D, Hu TT, Mast J, SunayamaMorita T, Stern DL. 2011. Multiplexed shotgun genotyping for rapid and efficient genetic mapping. Genome Res 21: 610-617.

Andrews KR, Good JM, Miller MR, Luikart G, Hohenlohe PA. 2016. Harnessing the power of RADseq for ecological and evolutionary genomics. Nat Rev Genet 17: 81-92.

Ao J, Li J, You X, Mu Y, Ding Y, Mao K, Bian C, Mu P, Shi Q, Chen X. 2015. Construction of the high-density genetic linkage map and chromosome map of large yellow croaker (Larimichthys crocea). Int J Mol Sci 16: 26237-26248.

Aoki JY, Kai W, Kawabata Y, Ozaki A, Yoshida K, Koyama T, Sakamoto T, Araki K. 2015. Second generation physical and linkage maps of yellowtail (Seriola quinqueradiata) and comparison of synteny with four model fish. BMC Genomics 16: 406.

Baird NA, Etter PD, Atwood TS, Currey MC, Shiver AL, Lewis ZA, Selker EU, Cresko WA, Johnson EA. 2008. Rapid SNP discovery and genetic mapping using sequenced RAD markers. PLOS ONE 3: e3376.

Bangera R, Correa K, Lhorente JP, Figueroa R, Yanez JM. 2017. Genomic predictions can accelerate selection for resistance against Piscirickettsia salmonis in Atlantic salmon (Salmo salar). BMC Genomics 18: 121.

Baptista M, Repolho T, Maulvault AL, Lopes VM, Narciso L, Marques A, Bandarra N, Rosa R. 2014. Temporal dynamics of amino and fatty acid composition in the razor clam Ensis siliqua (Mollusca: Bivalvia). Helgol Mar Res 68: 465-482.

Baranski M, Gopikrishna G, Robinson NA, Katneni VK, Shekhar MS, Shanmugakarthik J, Jothivel S, Gopal C, Ravichandran P, Kent M, Arnyasi M, Ponniah AG. 2014. The development of a high density linkage map for black tiger shrimp (Penaeus monodon) based on cSNPs. PLOS ONE 9: e 85413.

Ben Ayed R, Ennouri K, Ben Hlima H, Smaoui S, Hanana M, Mzid R, Ercisli S, Rebai A. 2017. Identification and characterization of single nucleotide polymorphism markers in FADS2 gene associated with olive oil fatty acids composition. Lipids Health Dis 16: 138.

Bernas R, Pocwierz-Kotus A, Debowski P, Wenne R. 2016. The genetic relationship between extirpated and contemporary Atlantic salmon Salmo salar L. lines from the southern Baltic Sea. Genet Sel Evol: GSE 48: 29.

Besnier F, Kent M, Skern-Mauritzen R, Lien S, Malde K, Edvardsen RB, Taylor S, Ljungfeldt LER, Nilsen F, Glover KA. 2014. Human-induced evolution caught in action: SNP-array reveals rapid amphi-atlantic spread of pesticide resistance in the salmon ecotoparasite Lepeophtheirus salmonis. BMC Genomics 15: 937.

Boichard D, Ducrocq V, Croiseau P, Fritz S. 2016. Genomic selection in domestic animals: Principles, applications and perspectives. $C R$ Biol 339: 274-277.

Boulding EG, Culling M, Glebe B, Berg PR, Lien S, Moen T. 2008. Conservation genomics of Atlantic salmon: SNPs associated with QTLs for adaptive traits in parr from four trans-Atlantic backcrosses. Heredity (Edinb) 101: 381-391.
Bourret V, O'Reilly PT, Carr JW, Berg PR, Bernatchez L. 2011. Temporal change in genetic integrity suggests loss of local adaptation in a wild Atlantic salmon (Salmo salar) population following introgression by farmed escapees. Heredity 106:500-510.

Brown JK, Taggart JB, Bekaert M, Wehner S, Palaiokostas C, Setiawan AN, Symonds JE, Penman DJ. 2016. Mapping the sex determination locus in the hapuku (Polyprion oxygeneios) using ddRAD sequencing. BMC Genomics 17: 448.

Brynildsrud O, Feil EJ, Bohlin J, Castillo-Ramirez S, Colquhoun D, McCarthy U, Matejusova IM, Rhodes LD, Wiens GD, VernerJeffreys DW. 2014. Microevolution of Renibacterium salmoninarum: evidence for intercontinental dissemination associated with fish movements. ISME $J$ 8: 746-756.

Bylemans J, Maes GE, Diopere E, Cariani A, Senn H, Taylor MI, Helyar S, Bargelloni L, Bonaldo A, Carvalho G, Guarniero I, Komen H, Martinsohn JT, Nielsen EE, Tinti F, Volckaert FAM, Ogden R. 2016. Evaluating genetic traceability methods for captive-bred marine fish and their applications in fisheries management and wildlife forensics. Aquac Environ Interact 8: 131-145.

Calhoun WE, Shelton WL. 1983. Sex-ratios of progeny from mass spawnings of sex-reversed broodstock of Tilapia nilotica. Aquaculture 33: 365-371.

Castaño-Sánchez C, Fuji K, Ozaki A, Hasegawa O, Sakamoto T, Morishima K, Nakayama I, Fujiwara A, Masaoka T, Okamoto H, Hayashida K, Tagami M, Kawai J, Hayashizaki Y, Okamoto N. 2010. A second generation genetic linkage map of Japanese flounder (Paralichthys olivaceus). BMC Genomics 11: 554.

Correa K, Bangera R, Figueroa R, Lhorente JP, Yanez JM. 2017. The use of genomic information increases the accuracy of breeding value predictions for sea louse (Caligus rogercresseyi) resistance in Atlantic salmon (Salmo salar). Genet Sel Evol: GSE 49: 15.

Correa K, Lhorente JP, Lopez ME, Bassini L, Naswa S, Deeb N, Di Genova A, Maass A, Davidson WS, Yanez JM. 2015. Genomewide association analysis reveals loci associated with resistance against Piscirickettsia salmonis in two Atlantic salmon (Salmo salar L.) chromosomes. BMC Genomics 16: 854.

Cosenza G, Macciotta NPP, Nudda A, Coletta A, Ramunno L, Pauciullo A. 2017. A novel polymorphism in the oxytocin receptor encoding gene (OXTR) affects milk fatty acid composition in Italian Mediterranean river buffalo. J Dairy Res 84: 170-180.

Cui Z, Li X, Liu Y, Song C, Hui M, Shi G, Luo D, Li Y. 2013. Transcriptome profiling analysis on whole bodies of microbial challenged Eriocheir sinensis larvae for immune gene identification and SNP development. PLOS ONE 8: e 82156.

Cui Z, Liu Y, Wang W, Wang Q, Zhang N, Lin F, Wang N, Shao C, Dong Z, Li Y, Yang Y, Hu M, Li H, Gao F, Wei Z, Meng L, Liu Y, Wei M, Zhu Y, Guo H, Cheng CH, Schartl M, Chen S. 2017. Genome editing reveals dmrt as an essential male sexdetermining gene in Chinese tongue sole (Cynoglossus semilaevis). Sci Rep 7: 42213.

Dai P, Huan P, Wang H, Lu X, Liu B. 2015. Characterization of a longchain fatty acid-CoA ligase 1 gene and association between its SNPs and growth traits in the clam Meretrix meretrix. Gene 566: 194-200.

Danzmann RG, Kocmarek AL, Norman JD, Rexroad 3rd CE, Palti Y. 2016. Transcriptome profiling in fast versus slow-growing rainbow trout across seasonal gradients. BMC Genomics 17: 60.

Davey JW, Cezard T, Fuentes-Utrilla P, Eland C, Gharbi K, Blaxter ML. 2013. Special features of RAD Sequencing data: implications for genotyping. Mol Ecol 22: 3151-3164.

Dehler CE, Boudinot P, Martin SA, Collet B. 2016. Development of an Efficient Genome Editing Method by CRISPR/Cas9 in a Fish Cell Line. Mar Biotechnol 18: 449-452. 
Dominik S, Henshall JM, Kube PD, King H, Lien S, Kent MP, Elliott NG. 2010. Evaluation of an Atlantic salmon SNP chip as a genomic tool for the application in a Tasmanian Atlantic salmon (Salmo salar) breeding population. Aquaculture 308: S56-S61.

Dong Y, Li Q, Zhong X, Kong L. 2016. Development of Gene-derived SNP Markers and Their Application for the Assessment of Genetic Diversity in Wild and Cultured Populations in Sea Cucumber, Apostichopus japonicus. J World Aquac Soc 47: 873-888.

Drywa A, Pocwierz-Kotus A, Was A, Dobosz S, Kent MP, Lien S, Bernas R, Wenne R. 2013. Genotyping of two populations of Southern Baltic Sea trout Salmo trutta m. trutta using an Atlantic salmon derived SNP-array. Mar Genomics 9: 25-32.

Du ZQ, Ciobanu DC, Onteru SK, Gorbach D, Mileham AJ, Jaramillo G, Rothschild MF. 2010. A gene-based SNP linkage map for pacific white shrimp, Litopenaeus vannamei. Anim Genet 41: 286294.

Du X, Li L, Zhang S, Meng F, Zhang G. 2014. SNP identification by transcriptome sequencing and candidate gene-based association analysis for heat tolerance in the bay scallop Argopecten irradians. PLOS ONE 9: e 104960.

Dunham RA, Taylor JF, Rise ML, Liu Z. 2014. Development of strategies for integrated breeding, genetics and applied genomics for genetic improvement of aquatic organisms. Aquaculture 420: S121-S123.

Eisbrenner WD, Botwright N, Cook M, Davidson EA, Dominik S, Elliott NG, Henshall J, Jones SL, Kube PD, Lubieniecki KP, Peng S, Davidson WS. 2014. Evidence for multiple sex-determining loci in Tasmanian Atlantic salmon (Salmo salar). Heredity (Edinb) 113: 86-92.

Elshire R.J., Glaubitz JC, Sun Q, Poland JA, Kawamoto K, Buckler ES, Mitchell SE. 2011. A Robust, Simple Genotyping-bySequencing (GBS) approach for high diversity species. PLOS ONE 6: e 19379.

Espinoza-Valles I, Vora GJ, Lin B, Leekitcharoenphon P, GonzalezCastillo A, Ussery D, Hoj L, Gomez-Gil B. 2015. Unique and conserved genome regions in Vibrio harveyi and related species in comparison with the shrimp pathogen Vibrio harveyi CAIM 1792. Microbiol 161: 1762-1779.

Everett MV, Seeb JE. 2014. Detection and mapping of QTL for temperature tolerance and body size in Chinook salmon (Oncorhynchus tshawytscha) using genotyping by sequencing. Evol Appl 7: 480-492.

FAO. 2016. The State of World Fisheries and Aquaculture 2016. Contributing to food security and nutrition for all. Rome: FAO, $200 \mathrm{pp}$.

FAO. 2017. Genome-based biotechnologies in aquaculture.

Feng L, Li X, Yu Q, Ning X, Dou J, Zou J, Zhang L, Wang S, Hu X, Bao Z. 2014. A scallop IGF binding protein gene: molecular characterization and association of variants with growth traits. PLOS ONE 9: e 89039.

Fernandes MB, Caldas HC, Martins LR, Ferreira CC, Baptista MA, Fernandes IM, Abbud-Filho M. 2012. Effects of polyunsaturated fatty acids (PUFAs) in the treatment of experimental chronic renal failure. Int Nephrol 44: 1571-1576.

Fu GH, Bai ZY, Xia JH, Liu XJ, Liu F, Wan ZY, Yue GH. 2014a. Characterization of the LECT2 gene and its associations with resistance to the big belly disease in Asian seabass. Fish Shellfish Immunol 37: 131-138.

Fu GH, Liu F, Xia JH, Yue GH. 2014b. The LBP gene and its association with resistance to Aeromonas hydrophila in tilapia. Int J Mol Sci 15: 22028-22041.

Fu GH, Wan ZY, Xia JH, Liu F, Liu XJ, Yue GH. 2014c. The MCP-8 gene and its possible association with resistance to Streptococcus agalactiae in tilapia. Fish Shellfish Immunol 40: 331-336.
Garcia F, Romera DM, Sousa NS, Paiva-Ramos I, Onaka EM. 2016. The potential of periphyton-based cage culture of Nile tilapia in a Brazilian reservoir. Aquaculture 464: 229-235.

García-Ortega A, Kissinger KR, Trushenski JT. 2016. Evaluation of fish meal and fish oil replacement by soybean protein and algal meal from Schizochytrium limacinum in diets for giant grouper Epinephelus lanceolatus. Aquaculture 452: 1-8.

Gjedrem T. 2012. Genetic improvement for the development of efficient global aquaculture: a personal opinion review. Aquaculture 344 349: 12-22.

Gjedrem T, Robinson N, Rye M. 2012. The importance of selective breeding in aquaculture to meet future demands for animal protein: a review. Aquaculture 350-353: 117-129.

Glover KA, Pertoldi C, Besnier F, Wennevik V, Kent M, Skaala O, 2013. Atlantic salmon populations invaded by farmed escapees: quantifying genetic introgression with a Bayesian approach and SNPs. BMC Genetics 14: 74.

Gonen S, Lowe NR, Cezard T, Gharbi K, Bishop SC, Houston RD. 2014. Linkage maps of the Atlantic salmon (Salmo salar) genome derived from RAD sequencing. BMC Genomics 15: 166.

Gonzalez-Pena D, Gao G, Baranski M, Moen T, Cleveland BM, Kenney PB, Vallejo RL, Palti Y, Leeds TD. 2016. Genome-wide association study for identifying loci that affect fillet yield, carcass, and body weight traits in rainbow trout (Oncorhynchus mykiss). Front Genet 7: 203.

Guo H, Bao Z, Li J, Lian S, Wang S, He Y, Fu X, Zhang L, Hu X. 2012. Molecular characterization of TGF-beta type I receptor gene (Tgfbr1) in Chlamys farreri, and the association of allelic variants with growth traits. PLOS ONE 7: e 51005.

Gutierrez AP, Lubieniecki KP, Davidson EA, Lien S, Kent MP, Fukui S, Withler RE, Swift B, Davidson WS. 2012. Genetic mapping of quantitative trait loci (QTL) for body-weight in Atlantic salmon (Salmo salar) using a 6.5K SNP array. Aquaculture 358-359: 61-70.

Gutierrez AP, Yanez JM, Fukui S, Swift B, Davidson WS. 2015. Genomewide association study (GWAS) for growth rate and age at sexual maturation in Atlantic salmon (Salmo salar). PLOS ONE 10: e 0119730.

Gutierrez AP, Yanez JM, Davidson WS. 2016. Evidence of recent signatures of selection during domestication in an Atlantic salmon population. Mar Genomics 26: 41-50.

Hao G, Lin F, Mu C, Li R, Yao J, Yuan X, Pan X, Shen J, Wang C. 2015. SNP E4-205C/T in C-type lectin of Portunus trituberculatus is association with susceptibility/resistance to Vibrio alginolyticus challenge. Aquaculture 442: 125-131.

Hayes B, Sonesson AK, Gjerde B. 2005. Evaluation of three strategies using DNA markers for traceability in aquaculture species. Aquaculture 250: 70-81.

Heino M, Svåsand T, Wennevik V, Glover KA. 2015. Genetic introgression of farmed salmon in native populations: quantifying the relative influence of population size and frequency of escapees. Aquac Environ Interact 6: 185-190.

Houston RD, Davey JW, Bishop SC, Lowe NR, Mota-Velasco JC, Hamilton A, Guy DR, Tinch AE, Thomson ML, Blaxter ML, Gharbi K, Bron JE, Taggart JB. 2012. Characterisation of QTLlinked and genome-wide restriction site-associated DNA (RAD) markers in farmed Atlantic salmon. BMC Genomics 13: 244.

Houston RD, Taggart JB, Cezard T, Bekaert M, Lowe NR, Downing A, Talbot R, Bishop SC, Archibald AL, Bron JE, Penman DJ, Davassi A, Brew F, Tinch AE, Gharbi K, Hamilton A. 2014. Development and validation of a high density SNP genotyping array for Atlantic salmon (Salmo salar). BMC Genomics 15: 90.

Jarzebski A, Polak L, Wenne R, Falkowski L. 1986a. Microgeographic differentiation in the lipid-composition of the bivalve macoma-balthica from the Gulf of Gdansk (Southern Baltic). Mar Biol 91: 27-31. 
Jarzebski, A., Wenne, R., 1990. Sterol composition of marine bivalves from the genus macoma. Comp Biochem Physiol B: Biochem Mol Biol 97: 81-82.

Jarzebski A, Wenne R, Habermehl G. 1986b. Anatomical distribution of lipids and sterols in Macoma balthica (L.). Comp Biochem Physiol B: Biochem Mol Biol 85: 135-137.

Jenneckens I, Meyer JN, Horstgen-Schwark G, May B, Debus L, Wedekind H, Ludwig A. 2001. A fixed allele at microsatellite locus LS-39 exhibiting species-specificity for the black caviar producer Acipenser stellatus. J Appl Ichthyol[Z Angew Ichthyol] 17: $39-42$.

Jia ZY, Ge HZ, Bai YY, Li CT, Shi LY. 2015. Characterization and SNP variation of the interleukin-1 $\beta$ gene of bighead carp (Cyprinus pellegrini Tchang, 1933) and five strains of common carp [Cyprinus carpio Linnaeus (1758)] in China. J Appl Ichthyol 31: 1102-1106.

Jiang L, Li HD. 2017. Single locus maintains large variation of sex reversal in Half-Smooth Tongue Sole (Cynoglossus semilaevis). G3-Genes Genomes Genet 7: 583-589.

Jilberto F, Araneda C, Larrain MA. 2017. High resolution melting analysis for identification of commercially-important Mytilus species. Food Chem 229: 716-720.

Jin SB, Zhang XF, Lu JG, Fu HT, Jia ZY, Sun XW. 2015a. Genetic analysis of QTL for eye cross and eye diameter in common carp (Cyprinus carpio L.) using microsatellites and SNPs. Genet Mol Res 14: 3557-3569.

Jin SB, Zhang Y, Dong XL, Xi QK, Song D, Fu HT, Sun DJ. 2015 b. Comparative transcriptome analysis of testes and ovaries for the discovery of novel genes from Amur sturgeon (Acipenser schrenckii). Genet Mol Res: GMR 14: 18913-18927.

Jones DB, Jerry DR, Khatkar MS, Raadsma HW, Zenger KR. 2013. A high-density SNP genetic linkage map for the silver-lipped pearl oyster, Pinctada maxima:a valuable resource for gene localisation and marker-assisted selection. BMC Genomics 14: 810.

Jung H, Lyons RE, Li Y, Thanh NM, Dinh H, Hurwood DA, Salin KR, Mather PB. 2014. A candidate gene association study for growth performance in an improved giant freshwater prawn (Macrobrachium rosenbergii) culture line. Mar Biotechnol 16: 161-180.

Kai W, Nomura K, Fujiwara A, Nakamura Y, Yasuike M, Ojima N, Masaoka T, Ozaki A, Kazeto Y, Gen K, Nagao J, Tanaka H, Kobayashi T, Ototake M. 2014. A ddRAD-based genetic map and its integration with the genome assembly of Japanese eel (Anguilla japonica) provides insights into genome evolution after the teleost-specific genome duplication. BMC Genomics 15: 233.

Kakioka R, Kokita T, Kumada H, Watanabe K, Okuda N. 2013. A RAD-based linkage map and comparative genomics in the gudgeons (genus Gnathopogon, Cyprinidae). BMC Genomics 14: 32.

Karlsson S, Moen T, Lien S, Glover KA, Hindar K. 2011. Generic genetic differences between farmed and wild Atlantic salmon identified from a 7K SNP-chip. Mol Ecol Res 11 Suppl 1: 247-253.

Kijas J, Elliot N, Kube P, Evans B, Botwright N, King H, Primmer CR, Verbyla K. 2016. Diversity and linkage disequilibrium in farmed Tasmanian Atlantic salmon. Anim Genet 48: 237-241.

Kijewski T, Wijsman JWM, Hummel H, Wenne R. 2009. Genetic composition of cultured and wild mussels Mytilus from The Netherlands and transfers from Ireland and Great Britain. Aquaculture 287: 292-296.

Kitaoka M, Okaniura N, Ichinose H, Goto M. 2008. Detection of SNPs in fish DNA: Application of the Fluorogenic ribonuclease protection (FRIP) assay for the authentication of food contents. $J$ Agric Food Chem 56: 6246-6251.

Klinbunga S, Sittikankaew K, Jantee N, Prakopphet S, Janpoom S, Hiransuchalert R, Menasveta P, Khamnamtong B. 2015. Expres- sion levels of vitellogenin receptor (Vtgr) during ovarian development and association between its single nucleotide polymorphisms (SNPs) and reproduction-related parameters of the giant tiger shrimp Penaeus monodon. Aquaculture 435: 18-27.

Kongchum P, Palti Y, Hallerman EM, Hulata G, David L. 2010. SNP discovery and development of genetic markers for mapping innate immune response genes in common carp (Cyprinus carpio). Fish Shellfish Immunol 29: 356-361.

Kuang YY, Zheng XH, Lv WH, Cao DC, Sun XW. 2015. Mapping quantitative trait loci for flesh fat content in common carp (Cyprinus carpio). Aquaculture 435: 100-105.

Kumar G, Kocour M. 2017. Applications of next-generation sequencing in fisheries research: A review. Fisheries Res 186: $11-22$.

Laghari MY, Lashari P, Zhang X, Xu P, Xin B, Zhang Y, Narejo NT, Sun X. 2014. Mapping quantitative trait loci (QTL) for body weight, length and condition factor traits in backcross (BC1) family of Common carp (Cyprinus carpio L.). Mol Biol Rep 41: 721-731.

Lal MM, Southgate PC, Jerry DR, Zenger KR. 2016. Fishing for divergence in a sea of connectivity: The utility of ddRADseq genotyping in a marine invertebrate, the black-lip pearl oyster Pinctada margaritifera. Mar Genomics 25: 57-68.

Leitwein M, Gagnaire PA, Desmarais E, Guendouz S, Rohmer M, Berrebi P, Guinand B. 2016. Genome-wide nucleotide diversity of hatchery-reared Atlantic and Mediterranean strains of brown trout Salmo trutta compared to wild Mediterranean populations. J Fish Biol 89: 2717-2734.

Li B, Fan SX, Yu FK, Chen Y, Zhang SR, Han FX, Yan SR, Wang LZ, Sun JM. 2017a. High-resolution mapping of QTL for fatty acid composition in soybean using specific-locus amplified fragment sequencing. Theor Appl Genet 130: 1467-1479.

Li C, Waldbieser G, Bosworth B, Beck BH, Thongda W, Peatman E. 2014. SNP discovery in wild and domesticated populations of blue catfish, Ictalurus furcatus, using genotyping-by-sequencing and subsequent SNP validation. Mol Ecol Res 14: 1261-1270.

Li M, Wang D. 2017. Gene editing nuclease and its application in tilapia. Sci Bull 62: 165-173.

Li S, Liu H, Bai J, Zhu X. 2017b. Transcriptome assembly and identification of genes and SNPs associated with growth traits in largemouth bass (Micropterus salmoides). Genetica 145: 175187.

Li W-s, Liu C, Zhang X, Zhang T, Wang X, Chu Z, Sun X. 2011. Mapping QTLs related to body weight of mirror carp (Cyprinus carpio L.). Jiyinzuxue Yu Yingyong Shengwuxue 30: 316-324.

Li X, Cui Z, Liu Y, Song C, Shi G, Wang C. 2013a. Polymorphisms of anti-lipopolysaccharide factors in the swimming crab Portunus trituberculatus and their association with resistance/susceptibility to Vibrio alginolyticus. Fish Shellfish Immunol 34: 1560-1568.

Li X, Meng X, Kong J, Luo K, Luan S, Cao B, Liu N, Pang J, Shi X. 2013b. Molecular cloning and characterization of a cathepsin B gene from the Chinese shrimp Fenneropenaeus chinensis. Fish Shellfish Immunol 35: 1604-1612.

Li Y, Liu S, Qin Z, Waldbieser G, Wang R, Sun L, Bao L, Danzmann RG, Dunham R, Liu Z. 2015. Construction of a high-density, highresolution genetic map and its integration with BAC-based physical map in channel catfish. DNA Res: An Int J Rapid Publication Rep Genes Genomes 22: 39-52.

Liao Z, Wan Q, Shang X, Su J. 2017. Large-scale SNP screenings identify markers linked with GCRV resistant traits through transcriptomes of individuals and cell lines in Ctenopharyngodon idella. Sci Rep 7: 1184.

Lien S, Gidskehaug L, Moen T, Hayes BJ, Berg PR, Davidson WS, Omholt SW, Kent MP. 2011. A dense SNP-based linkage map for 
Atlantic salmon (Salmo salar) reveals extended chromosome homeologies and striking differences in sex-specific recombination patterns. BMC Genomics 12: 615.

Lillehammer M, Meuwissen TH, Sonesson AK. 2013. A low-marker density implementation of genomic selection in aquaculture using within-family genomic breeding values. Genet sel evol: GSE 45: 39.

Lin Z, Qiao J, Zhang Y, Guo L, Huang H, Yan F, Li Y, Wang X. 2012. Cloning and characterisation of the SpToll gene from green mud crab, Scylla paramamosain. Dev Comp Immunol 37: 164-175.

Linlokken AN, Haugen TO, Kent MP, Lien S. 2017. Genetic differences between wild and hatchery-bred brown trout (Salmo trutta $L$.) in single nucleotide polymorphisms linked to selective traits. Ecol Evol 7: 4963-4972.

Liu H, Fu B, Pang M, Feng X, Yu X, Tong Y. 2017a. A High-Density Genetic Linkage Map and QTL Fine Mapping for Body Weight in Crucian Carp (Carassius auratus) Using 2b-RAD Sequencing. G3 7: 2473-2487.

Liu L, Ang KP, Elliott JAK, Kent MP, Lien S, MacDonald D, Boulding EG. 2017b. A genome scan for selection signatures comparing farmed Atlantic salmon with two wild populations: Testing colocalization among outlier markers, candidate genes, and quantitative trait loci for production traits. Evol Appl 10: 276296.

Liu S, Vallejo RL, Gao G, Palti Y, Weber GM, Hernandez A, Rexroad 3rd CE. 2015a. Identification of single-nucleotide polymorphism markers associated with cortisol response to crowding in rainbow trout. Mar Biotechnol 17: 328-337.

Liu S, Vallejo RL, Palti Y, Gao G, Marancik DP, Hernandez AG, Wiens GD. 2015b. Identification of single nucleotide polymorphism markers associated with bacterial cold water disease resistance and spleen size in rainbow trout. Front Genet 6: 298.

Liu S, Li Y, Qin Z, Geng X, Bao L, Kaltenboeck L, Kucuktas H, Dunham R, Liu Z. 2016. High-density interspecific genetic linkage mapping provides insights into genomic incompatibility between channel catfish and blue catfish. Anim Genet 47: 81-90.

Liu SK, Zhou ZC, Lu JG, Sun FY, Wang SL, Liu H, Jiang YL, Kucuktas H, Kaltenboeck L, Peatman E, Liu ZJ. 2011. Generation of genome-scale gene-associated SNPs in catfish for the construction of a high-density SNP array. BMC Genomics 12: 53.

Liu ZJ, Cordes JF. 2004. DNA marker technologies and their applications in aquaculture genetics. Aquaculture 238: 1-37.

Loukovitis D, Sarropoulou E, Batargias C, Apostolidis AP, Kotoulas G, Tsigenopoulos CS, Chatziplis D. 2012. Quantitative trait loci for body growth and sex determination in the hermaphrodite teleost fish Sparus aurata L. Anim Genet 43: 753-759.

Lu X, Luan S, Hu LY, Mao Y, Tao Y, Zhong SP, Kong J. 2016. Highresolution genetic linkage mapping, high-temperature tolerance and growth-related quantitative trait locus (QTL) identification in Marsupenaeus japonicus. Mol Genet Genomics: MGG 291: 13911405.

Lv J, Wang Y, Zhang D, Gao B, Liu P, Li J. 2015a. Cloning and characterization of calreticulin and its association with salinity stress in Portunus trituberculatus. Cell Stress Chaperones 20: 811-820.

Lv J, Zhang D, Gao B, Liu P, Li J. 2015b. Transcriptome and MassARRAY analysis for identification of transcripts and SNPs for growth traits of the swimming crab Portunus trituberculatus. Gene 566: 229-235.

Macqueen DJ, Primmer CR, Houston RD, Nowak BF, Bernatchez L, Bergseth S, Davidson WS, Gallardo-Escarate C, Goldammer T, Guiguen Y, Iturra P, Kijas JW, Koop BF, Lien S, Maass A, Martin SAM, McGinnity P, Montecino M, Naish KA, Nichols KM,
Olafsson K, Omholt SW, Palti Y, Plastow GS, Rexroad CER, Rise ML, Ritchie RJ, Sandve SR, Schulte PM, Tello A, Vidal R, Vik JO, Wargelius A, Yanez JM, Consortium F. 2017. Functional Annotation of All Salmonid Genomes (FAASG): an international initiative supporting future salmonid research, conservation and aquaculture. BMC Genomics 18: 484.

Mair GC, Scott AG, Penman DJ, Beardmore JA, Skibinski DOF. 1991. Sex determination in the genus oreochromis. 1. Sex reversal, gynogenesis and triploidy in Oreochromis niloticus (L). Theor Appl Genet 82: 144-152.

Makinen H, Vasemagi A, McGinnity P, Cross TF, Primmer CR. 2015. Population genomic analyses of early-phase Atlantic Salmon (Salmo salar) domestication/captive breeding. Evol Appl 8: 93107.

Martinez P, Vinas AM, Sanchez L, Diaz N, Ribas L, Piferrer F. 2014. Genetic architecture of sex determination in fish: applications to sex ratio control in aquaculture. Front Genet 5: 340.

McAndrew B, Napier J. 2010. Application of genetics and genomics to aquaculture development: current and future directions. J Agric Sci 149: 143-151.

McKinney GJ, Seeb LW, Larson WA, Gomez-Uchida D, Limborg MT, Brieuc MS, Everett MV, Naish KA, Waples RK, Seeb JE. 2016. An integrated linkage map reveals candidate genes underlying adaptive variation in Chinook salmon (Oncorhynchus tshawytscha). Mol Ecol Res 16: 769-783.

Meuwissen THE, Hayes BJ, Goddard ME. 2001. Prediction of total genetic value using genome-wide dense marker maps. Genet 157 : 1819-1829.

Miller MR, Dunham JP, Amores A, Cresko WA, Johnson EA. 2007. Rapid and cost-effective polymorphism identification and genotyping using restriction site associated DNA (RAD) markers. Genome Res 17: 240-248.

Moen T, Baranski M, Sonesson AK, Kjoglum S. 2009. Confirmation and fine-mapping of a major QTL for resistance to infectious pancreatic necrosis in Atlantic salmon (Salmo salar): populationlevel associations between markers and trait. BMC Genomics 10: 368.

Moen T. 2010. Breeding for resistance to viral diseases in salmonids. Breeding for disease resistance in farm animals, 3rd edn, in: Bishop SC, Axford RFE, Nicholas FW, Owen JB (Eds.), Cabi Publishing-C A B Int, Cabi Publishing, Wallingford 0x10 8de, Oxon, England, pp. 166-179.

Moen T, Hayes B, Baranski M, Berg PR, Kjoglum S, Koop BF, Davidson WS, Omholt SW, Lien S. 2008. A linkage map of the Atlantic salmon (Salmo salar) based on EST-derived SNP markers. BMC Genomics 9: 223.

Moen T, Torgersen J, Santi N, Davidson WS, Baranski M, Odegard J, Kjoglum S, Velle B, Kent M, Lubieniecki KP, Isdal E, Lien S. 2015. Epithelial Cadherin Determines Resistance to Infectious Pancreatic Necrosis Virus in Atlantic Salmon. Genet 200: 13131326.

Nguyen TTT, Hayes BJ, Ingram BA. 2014. Genetic parameters and response to selection in blue mussel (Mytilus galloprovincialis) using a SNP-based pedigree. Aquaculture 420: 295-301.

Ni J, You F, Xu J, Xu D, Wen A, Wu Z, Xu Y, Zhang P. 2012. Single nucleotide polymorphisms in intron 1 and intron 2 of Larimichthys crocea growth hormone gene are correlated with growth traits. Chin J Oceanol Limnol 30: 279-285.

Nunez-Acuna G, Valenzuela-Munoz V, Gallardo-Escarate C. 2014. High-throughput SNP discovery and transcriptome expression profiles from the salmon louse Caligus rogercresseyi (Copepoda: Caligidae). Comp Biochem Physiol. Part D, Genomics Proteomics $109-21$. 
Ogden R, Gharbi K, Mugue N, Martinsohn J, Senn H, Davey JW, Pourkazemi M, McEwing R, Eland C, Vidotto M, Sergeev A, Congiu L. 2013. Sturgeon conservation genomics: SNP discovery and validation using RAD sequencing. Mol Ecol 22: 3112-3123.

Oyarzún PA, Toro JE, Navarro JM. 2013. Comparison of the physiological energetics betweenMytilus chilensis, Mytilus galloprovincialis and their hybrids, under laboratory conditions. Aquac Res 44: 1805-1814.

Ozaki A, Yoshida K, Fuji K, Kubota M, Kai W, Aoki JY, Kawabata Y, Suzuki J, Akita K, Koyama T, Nakagawa M, Hotta T, Tsuzaki T, Okamoto N, Araki K, Sakamoto T. 2013. Quantitative Trait Loci (QTL) Associated with Resistance to a Monogenean Parasite (...) through Genome Wide Analysis. PLOS ONE 8: e64987.

Ozerov MY, Gross R, Bruneaux M, Vaha JP, Burimski O, Pukk L, Vasemagi A. 2016. Genomewide introgressive hybridization patterns in wild Atlantic salmon influenced by inadvertent gene flow from hatchery releases. Mol Ecol 25: 1275-1293.

Palaiokostas C, Bekaert M, Davie A, Cowan ME, Oral M, Taggart JB, Gharbi K, McAndrew BJ, Penman DJ, Migaud H. 2013a. Mapping the sex determination locus in the Atlantic halibut (Hippoglossus hippoglossus) using RAD sequencing. BMC Genomics 14: 566.

Palaiokostas C, Bekaert M, Khan MG, Taggart JB, Gharbi K, McAndrew BJ, Penman DJ. 2013b. Mapping and validation of the major sex-determining region in Nile tilapia (Oreochromis niloticus L.) Using RAD sequencing. PLOS ONE 8: e68389.

Palaiokostas C, Bekaert M, Taggart JB, Gharbi K, McAndrew BJ, Chatain B, Penman DJ, Vandeputte M. 2015. A new SNP-based vision of the genetics of sex determination in European sea bass (Dicentrarchus labrax). Genet Sel Evol: GSE 47: 68.

Palti Y, Gao G, Liu S, Kent MP, Lien S, Miller MR, Rexroad CE 3rd, Moen T. 2015a. The development and characterization of a $57 \mathrm{~K}$ single nucleotide polymorphism array for rainbow trout. Mol Ecol Resour 15: 662-672.

Palti Y, Vallejo RL, Gao G, Liu S, Hernandez AG, Rexroad 3rd CE, Wiens GD. 2015b. Detection and validation of QTL affecting bacterial cold water disease resistance in rainbow trout using restriction-site associated DNA sequencing. PLOS ONE 10: e0138435.

Penaloza C, Hamilton A, Guy DR, Bishop SC, Houston RD. 2013. A SNP in the 5' flanking region of the myostatin- $1 \mathrm{~b}$ gene is associated with harvest traits in Atlantic salmon (Salmo salar). BMC Genetics 14: 112.

Peterson BK, Weber JN, Kay EH, Fisher HS, Hoekstra HE. 2012. Double digest RADseq: an inexpensive method for de novo snp discovery and genotyping in model and non-model species. PLOS ONE 7: e37135.

Pino-Querido A, Álvarez-Castro JM, Vera M, Pardo BG, Fuentes J, Martínez P. 2015. A molecular tool for parentage analysis in the Mediterranean mussel (Mytilus galloprovincialis). Aquac Res 46: $1721-1735$.

Pocwierz-Kotus A, Bernas R, Debowski P, Kent MP, Lien S, Kesler M, Titov S, Leliuna E, Jespersen H, Drywa A, Wenne R. 2014. Genetic differentiation of southeast Baltic populations of sea trout inferred from single nucleotide polymorphisms. Anim Genet 45: 96-104.

Pocwierz-Kotus A, Bernas R, Kent MP, Lien S, Leliuna E, Debowski P, Wenne R. 2015. Restitution and genetic differentiation of salmon populations in the southern Baltic genotyped with the Atlantic salmon 7K SNP array. Genet Sel Evol: GSE 47: 39.

Polak L, Jarzebski A, Wenne R, Falkowski L. 1987. Seasonal-changes in condition and lipids composition of the bivalve Macoma balthica L. from the gulf of gdansk (Southern Baltic). Comp Biochem Physiol B: Biochem Mol Biol 88: 881-885.
Prasertlux S, Yocawibun P, Janpoom S, Klinbunga S, Menasveta P, Khamnamtong B. 2015. Differential expression of X-box binding protein 1 during ovarian development and association between its SNP and growth-related parameters of the giant tiger shrimp Penaeus monodon. Aquaculture 448: 531-538.

Pritchard VL, Erkinaro J, Kent MP, Niemela E, Orell P, Lien S, Primmer CR. 2016. Single nucleotide polymorphisms to discriminate different classes of hybrid between wild Atlantic salmon and aquaculture escapees. Evol Appl 9: 1017-1031.

Qi H, Liu X, Wu F, Zhang G. 2010. Development of gene-targeted SNP markers for genomic mapping in Pacific abalone Haliotis discus hannai Ino. Mol Biol Rep 37: 3779-3784.

Qu CM, Jia LD, Fu FY, Zhao HY, Lu K, Wei LJ, Xu XF, Liang Y, Li SM, Wang R, Li JN. 2017. Genome-wide association mapping and Identification of candidate genes for fatty acid composition in Brassica napus L. using SNP markers (vol 18, pg 232, 2017). BMC Genomics 18: 232.

Rabier CE, Barre P, Asp T, Charmet G, Mangin B. 2016. On the Accuracy of Genomic Selection. PLOS ONE 11: e 0156086.

Rengmark AH, Lingaas F. 2007. Genomic structure of the Nile tilapia (Oreochromis niloticus) transferrin gene and a haplotype associated with saltwater tolerance. Aquaculture 272: 146-155.

Rexroad CE, Palti Y, Gahr SA, Vallejo RL. 2008. A second generation genetic map for rainbow trout (Oncorhynchus mykiss). BMC Genetics 9: 74.

Robledo D, Fernandez C, Hermida M, Sciara A, Alvarez-Dios JA, Cabaleiro S, Caamano R, Martinez P, Bouza C. 2016. Integrative Transcriptome, Genome and Quantitative Trait Loci Resources Identify Single Nucleotide Polymorphisms in Candidate Genes for Growth Traits in Turbot. Int J Mol Sci 17: 243.

Robledo D, Palaiokostas C, Bargelloni L, Martínez P, Houston R. 2017. Applications of genotyping by sequencing in aquaculture breeding and genetics. Reviews in Aquaculture.

Robledo, D., Ribas, L., Cal, R., Sanchez, L., Piferrer, F., Martinez, P., Vinas, A., 2015. Gene expression analysis at the onset of sex differentiation in turbot (Scophthalmus maximus). BMC Genomics 16: 973.

Salazar S, Oliver C, Yanez AJ, Avendano-Herrera R. 2016. Comparative analysis of innate immune responses to Streptococcus phocae strains in Atlantic salmon (Salmo salar) and rainbow trout (Oncorhynchus mykiss). Fish shellfish Immunol 51: 97-103.

Salem M, Vallejo RL, Leeds TD, Palti Y, Liu S, Sabbagh A, Rexroad 3rd CE, Yao J, 2012. RNA-Seq identifies SNP markers for growth traits in rainbow trout. PLOS ONE 7: e36264.

Sansuwan K, Kovitvadhi S, Thongprajukaew K, Ozório ROA, Somsueb P, Kovitvadhi U. 2017. Microwave irradiation and pelleting method affected feed chemical composition and growth performance and feed utilization of sex-reversed Nile tilapia, Oreochromis niloticus (L.). Aquac Res 48, 1836-1848.

Sato S, Templin WD, Seeb LW, Seeb JE, Urawa S. 2014. Genetic structure and diversity of Japanese chum salmon populations inferred from single-nucleotide polymorphism markers. Trans Am Fish Soc 143: 1231-1246.

Sauvage C, Vagner M, Derome N, Audet C, Bernatchez L. 2012. Coding Gene SNP mapping reveals QTL linked to growth and stress response in Brook Charr (Salvelinus fontinalis). G3 2: 707-720.

Shao C, Niu Y, Rastas P, Liu Y, Xie Z, Li H, Wang L, Jiang Y, Tai S, Tian Y, Sakamoto T, Chen S. 2015. Genome-wide SNP identification for the construction of a high-resolution genetic map of Japanese flounder (Paralichthys olivaceus): applications to QTL mapping of Vibrio anguillarum disease resistance and comparative genomic analysis. DNA Res: An Int J rapid Publ Rep Genes Genomes 22: 161-170. 
Shen Y, Fu GH, Liu F, Yue GH. 2015. Characterization of the duodenase-1 gene and its associations with resistance to Streptococuus agalactiae in hybrid tilapia (Oreochromis spp.). Fish Shellfish Immunol 45: 717-724.

Shen Y, Ma K, Liu F, Yue GH. 2016a. Characterization of two novel gadd45a genes in hybrid tilapia and their responses to the infection of Streptococcus agalactiae. Fish Shellfish Immunol 54: 276-281.

Shen YB, Zhang JB, Fu JJ, Xu XY, Li JL, Wang RQ, Xuan YF. 2016 b. A $425 \mathrm{~T}>\mathrm{C}$ polymorphism in complement $\mathrm{C} 7$ association with resistance to Aeromonas hydrophila in grass carp. Genet Mol Res: GMR 15: UNSP gmr.15014526.

Sodeland M, Gaarder M, Moen T, Thomassen M, Kjøglum S, Kent M, Lien S. 2013. Genome-wide association testing reveals quantitative trait loci for fillet texture and fat content in Atlantic salmon. Aquaculture 408-409: 169-174.

Su J, Heng J, Huang T, Peng L, Yang C, Li Q. 2012. Identification, mRNA expression and genomic structure of TLR22 and its association with GCRV susceptibility/resistance in grass carp (Ctenopharyngodon idella). Dev Comp Immunol 36: 450-462.

Sun L, Liu S, Wang R, Jiang Y, Zhang Y, Zhang J, Bao L, Kaltenboeck L, Dunham R, Waldbieser G, Liu Z. 2014. Identification and analysis of genome-wide SNPs provide insight into signatures of selection and domestication in channel catfish (Ictalurus punctatus). PLOS ONE 9: e 109666.

Sun C, Niu Y, Ye X, Dong J, Hu W, Zeng Q, Chen Z, Tian Y, Zhang J, $\mathrm{Lu}$ M. 2017. Construction of a high-density linkage map and mapping of sex determination and growth-related loci in the mandarin fish (Siniperca chuatsi). BMC Genomics 18: 446.

Tao WJ, Boulding EG. 2003. Associations between single nucleotide polymorphisms in candidate genes and growth rate in Arctic charr (Salvelinus alpinus L.). Heredity (Edinb) 91: 60-69.

Toonen RJ, Puritz JB, Forsman ZH, Whitney JL, Fernandez-Silva I, Andrews KR, Bird CE. 2013. ezRAD: a simplified method for genomic genotyping in non-model organisms. PeerJ 1: e 203.

Tsai HY, Hamilton A, Guy DR, Tinch AE, Bishop SC, Houston RD. 2015a. The genetic architecture of growth and fillet traits in farmed Atlantic salmon (Salmo salar). BMC Genetics 16: 51.

Tsai HY, Hamilton A, Guy DR, Tinch AE, Bishop SC, Houston RD. 2016. Verification of SNPs Associated with growth traits in two populations of farmed Atlantic Salmon. Int J Mol Sci 17: 5.

Tsai HY, Hamilton A, Tinch AE, Guy DR, Bron JE, Taggart JB, Gharbi K, Stear M, Matika O, Pong-Wong R, Bishop SC, Houston RD. 2016a. Genomic prediction of host resistance to sea lice in farmed Atlantic salmon populations. Genet sel evol: GSE 48: 47.

Tsai HY, Hamilton A, Tinch AE, Guy DR, Gharbi K, Stear MJ, Matika O, Bishop SC, Houston RD. 2015c. Genome wide association and genomic prediction for growth traits in juvenile farmed Atlantic salmon using a high density SNP array. BMC Genomics 16: 969.

Tsai HY, Robledo D, Lowe NR, Bekaert M, Taggart JB, Bron JE, Houston RD. 2016b. Construction and annotation of a high density SNP linkage map of the Atlantic Salmon (Salmo salar) Genome. G3 6: 2173-2179.

Tsigenopoulos CS, Louro B, Chatziplis D, Lagnel J, Vogiatzi E, Loukovitis D, Franch R, Sarropoulou E, Power DM, Patarnello T, Mylonas CC, Magoulas A, Bargelloni L, Canario A, Kotoulas G. 2014. Second generation genetic linkage map for the gilthead sea bream Sparus aurata L. Mar Gen 18 Pt A: 77-82.

Tur JA, Bibiloni MM, Sureda A, Pons A. 2012. Dietary sources of omega 3 fatty acids: public health risks and benefits. Br J nutr 107 Suppl 2: S23-52.

Vallejo RL, Leeds TD, Fragomeni BO, Gao G, Hernandez AG, Misztal I, Welch TJ, Wiens GD, Palti Y. 2016. Evaluation of genome-enabled selection for bacterial cold water disease resistance using progeny performance data in rainbow trout: insights on genotyping methods and genomic prediction models. Front genet 7: 96.

Vallejo RL, Leeds TD, Gao G, Parsons JE, Martin KE, Evenhuis JP, Fragomeni BO, Wiens GD, Palti Y. 2017. Genomic selection models double the accuracy of predicted breeding values for bacterial cold water disease resistance compared to a traditional pedigree-based model in rainbow trout aquaculture. Genet Sel Evol 49: 17.

van Son M, Enger EG, Grove H, Ros-Freixedes R, Kent MP, Lien S, Grindflek E. 2017. Genome-wide association study confirm major QTL for backfat fatty acid composition on SSC14 in Duroc pigs. BMC Genomics 18: 369.

Vasemagi A, Nilsson J, McGinnity P, Cross T, O’Reilly P, Glebe B, Peng B, Berg PR, Primmer CR. 2012. Screen for footprints of selection during domestication/captive breeding of Atlantic Salmon. Comp Funct Genomics 2012: 628204.

Vera M, Pardo BG, Pino-Querido A, Álvarez-Dios JA, Fuentes J, Martínez P. 2010. Characterization of single-nucleotide polymorphism markers in the Mediterranean mussel, Mytilus galloprovincialis. Aquac Res 41: e568-e 575.

Vervalle J, Hepple J.-A, Jansen S, Plessis JD, Wang P, Rhode C, Roodt-Wilding R. 2013. Integrated Linkage Map of Haliotis midae Linnaeus Based on Microsatellite and SNP Markers. $J$ Shellfish Res 32: 89-103.

Wang, S., Meyer, E., McKay, JK., Matz, MV., 2012. 2b-RAD: a simple and flexible method for genome-wide genotyping. Nat Methods 9: 808.

Wang G, Li X, Li J. 2013. Association between SNPs in interferon regulatory factor 2 (IRF-2) gene and resistance to Aeromonas hydrophila in freshwater mussel Hyriopsis cumingii. Fish Shellfish Immunol 34: 1366-1371.

Wang L, Wan ZY, Bai B, Huang SQ, Chua E, Lee M, Pang HY, Wen YF, Liu P, Liu F, Sun F, Lin G, Ye BQ, Yue GH. 2015a. Construction of a high-density linkage map and fine mapping of QTL for growth in Asian seabass. Sci Rep 5: 16358.

Wang W, Hu Y, Ma Y, Xu L, Guan J, Kong J. 2015b. High-density genetic linkage mapping in turbot (Scophthalmus maximus L.) based on SNP markers and major sex- and growth-related regions detection. PLOS ONE 10: e 0120410.

Wang L, Liu P, Huang SQ, Ye BQ, Chua E, Wan ZY, Yue GH. 2017. Genome-Wide association study identifies Loci associated with resistance to viral nervous Necrosis disease in Asian Seabass. Mar Biotechnol 19: 255-265.

Wenne R, Boudry P, Hemmer-Hansen J, Lubieniecki KP, Was A, Kause A. 2007. What role for genomics in fisheries management and aquaculture? Aquat Living Resour 20: 241-255.

Wenne R, Bach L, Zbawicka M, Strand J, McDonald JH. 2016a. A first report on coexistence and hybridization of Mytilus trossulus and M-edulis mussels in Greenland. Polar Biol 39: 343-355.

Wenne R, Bernas R, Pocwierz-Kotus A, Drywa A, Was A. 2016 b. Recent genetic changes in enhanced populations of sea trout (Salmo trutta m. trutta) in the southern Baltic rivers revealed with SNP analysis. Aquat Living Resour 29: 103.

Wenne R, Drywa A, Kent MP, Sundsaasen KK, Lien S. 2016c. SNParrays for species identification in salmonids. In: Bourlat SJ, ed. Marine genomics: methods and protocols, methods in molecular biology. Springer protocols. New York: Humana Press, Springer Nature, Springer Science+Business Media, Vol. 1452, Chapter 11, pp. 97-111.

Wenne R, Polak L. 1989. Lipid-composition and storage in the tissues of the bivalve, Macoma balthica. Biochem Systematics Ecol 17: 583-587. 
Wenne R, Styczynska-Jurewicz E. 1987. Gross biochemicalcomposition of the bivalve Macoma-balthica from the Gulf of Gdansk (southern Baltic). Mar Biol 96 73-78.

Wennerstrom L, Laikre L, Ryman N, Utter FM, Ab Ghani NI, Andre C, DeFaveri J, Johansson D, Kautsky L, Merila J, Mikhailova N, Pereyra R, Sandstrom A, Teacher AGF, Wenne R, Vasemagi A, Zbawicka M, Johannesson K, Primmer CR. 2013. Genetic biodiversity in the Baltic Sea: species-specific patterns challenge management. Biodivers Conserv 22: 3045-3065.

Xia JH, Lin G, He X, Yunping B, Liu P, Liu F, Sun F, Tu R, Yue GH. 2014. Mapping quantitative trait loci for omega-3 fatty acids in Asian seabass. Mar Biotechnol 16: 1-9.

Xia JH, Lin G, He XP, Liu P, Liu F, Sun F, Tu RJ, Yue GH. 2013. Whole genome scanning and association mapping identified a significant association between growth and a SNP in the IFABP-a gene of the Asian seabass. BMC Genomics 14: 295.

Xiao SJ, Wang PP, Dong LS, Zhang YG, Han ZF, Wang QR, Wang ZY. 2016. Whole-genome single-nucleotide polymorphism (SNP) marker discovery and association analysis with the eicosapentaenoic acid (EPA) and docosahexaenoic acid (DHA) content in Larimichthys crocea. PeerJ 4, e 2664.

$\mathrm{Xu}$ D, Lou B, Xu H, Li S, Geng Z. 2013. Isolation and characterization of male-specific DNA markers in the rock bream Oplegnathus fasciatus. Mar Biotechnol 15: 221-229.

Xu P, Zhang X, Wang X, Li J, Liu G, Kuang Y, Xu J, Zheng X, Ren L, Wang G, Zhang Y, Huo L, Zhao Z, Cao D, Lu C, Li C, Zhou Y, Liu Z, Fan Z, Shan G, Li X, Wu S, Song L, Hou G, Jiang Y, Jeney Z, Yu D, Wang L, Shao C, Song L, Sun J, Ji P, Wang J, Li Q, Xu L, Sun F, Feng J, Wang C, Wang S, Wang B, Li Y, Zhu Y, Xue W, Zhao L, Wang J, Gu Y, Lv W, Wu K, Xiao J, Wu J, Zhang Z, Yu J, Sun X. 2014. Genome sequence and genetic diversity of the common carp, Cyprinus carpio. Nat Genet 46, 1212-1219.

Yáñez JM, Naswa S, Lopez ME, Bassini L, Correa K, Gilbey J, Bernatchez L, Norris A, Neira R, Lhorente JP, Schnable PS, Newman S, Mileham A, Deeb N, Di Genova A, Maass A. 2016. Genomewide single nucleotide polymorphism discovery in Atlantic salmon (Salmo salar): validation in wild and farmed American and European populations. Mol Ecol Res 16: 1002-1011.

Yáñez JM, Newman S, Houston RD. 2015. Genomics in aquaculture to better understand species biology and accelerate genetic progress. Front Genet 6: 128.

Yang C, Wang L, Jiang Q, Wang J, Yue F, Zhang H, Sun Z, Song L. 2013. The polymorphism in the promoter region of metallothionein 1 is associated with heat tolerance of scallop Argopecten irradians. Gene 526: 429-436.

Yang C, Wang L, Liu C, Zhou Z, Zhao X, Song L. 2015. The polymorphisms in the promoter of HSP90 gene and their association with heat tolerance of bay scallop. Cell Stress Chaperones 20: 297-308.

Yang Y.-H, Liang X.-F, Fang R, Peng M.-Y, Huang Z. -D. 2011. Polymorphism of SNPs in the lipoprotein lipase (LPL) in Siniperca chuatsi and their association with feed habit domestication. Yichuan, 33: 996-1002, 2011.

Yin Q, Peng J.-X, Cui L, Xie D.-X, Wang Z.-W, Li K, Chen X.-H. 2011. Molecular cloning of Litopenaeus vannamei TCP-1-eta gene and analysis on its relationship with cold tolerance. Yichuan 33: $168-174$.

You XX, Shu LP, Li SS, Chen JM, Luo J, Lu J, Mu Q, Bai J, Xia QJ, Chen QC, Cai YJ, Zhang HF, Chen GH, Lin HR, Zhang Y, Shi Q. 2013. Construction of high-density genetic linkage maps for orange-spotted grouper Epinephelus coioides using multiplexed shotgun genotyping. BMC Genet 14: 113.

Yue GH. 2014. Recent advances of genome mapping and markerassisted selection in aquaculture. Fish Fish 15: 376-396.

Yue GH, Wang L. 2017. Current status of genome sequencing and its applications in aquaculture. Aquac 468: 337-347.

Zbawicka M, Drywa A, Smietanka B, Wenne R. 2012. Identification and validation of novel SNP markers in European populations of marine Mytilus mussels. Mar Biol 159: 1347-1362.

Zbawicka M., Sanko T., Strand J., Wenne R. 2014. New SNP markers reveal largely concordant clinal variation across the hybrid zone between Mytilus spp. in the Baltic Sea. Aquat Biol 21: 25.

Zeng Q.F., Fu Q., Li Y., Waldbieser G., Bosworth B., Liu S.K., Yang Y.J., Bao L.S., Yuan Z.H., Li N., Liu Z.L. 2017. Development of a $690 \mathrm{~K} \mathrm{SNP}$ array in catfish and its application for genetic mapping and validation of the reference genome sequence. Sci Rep 7: 40347.

Zhang B, Chen N, Huang C, Huang C, Chen B, Liu H, Wang W, Gul Y, Wang H. 2016. Molecular response and association analysis of Megalobrama amblycephala fih-1 with hypoxia. Mol Genet Genomics: $M G G$ 291: 1615-1624.

Zhou T, Liu S, Geng X, Jin Y, Jiang C, Bao L, Yao J, Zhang Y, Zhang J, Sun L, Wang X, Li N, Tan S, Liu Z. 2017. GWAS analysis of QTL for enteric septicemia of catfish and their involved genes suggest evolutionary conservation of a molecular mechanism of disease resistance. Mol Genet Genomics: $M G G$ 292: 231-242.

Zhu B, Niu H, Zhang WG, Wang ZZ, Liang YH, Guan L, Guo P, Chen Y, Zhang LP, Guo Y, Ni HM, Gao X, Gao HJ, Xu LY, Li JY. 2017. Genome wide association study and genomic prediction for fatty acid composition in Chinese Simmental beef cattle using high density SNP array. BMC Genomics 18: 464.

Cite this article as: Wenne R. 2018. Single nucleotide polymorphism markers with applications in aquaculture and assessment of its impact on natural populations. Aquat. Living Resour. 31: 2 